Louisiana State University

LSU Digital Commons

$8-21-2017$

\title{
Synthesis and Characterization of Pt(II) Complexes with Pyridyl Ligands: Elongated Octahedral Ion Pairs and Other Factors Influencing ${ }^{1} \mathrm{H}$ NMR Spectra
}

\author{
Nerissa A. Lewis \\ Louisiana State University \\ Svetlana Pakhomova \\ Louisiana State University \\ Patricia A. Marzilli \\ Louisiana State University \\ Luigi G. Marzilli \\ Louisiana State University
}

Follow this and additional works at: https://digitalcommons.Isu.edu/biosci_pubs

\section{Recommended Citation}

Lewis, N., Pakhomova, S., Marzilli, P., \& Marzilli, L. (2017). Synthesis and Characterization of Pt(II)

Complexes with Pyridyl Ligands: Elongated Octahedral Ion Pairs and Other Factors Influencing ${ }^{1} \mathrm{H}$ NMR

Spectra. Inorganic Chemistry, 56 (16), 9781-9793. https://doi.org/10.1021/acs.inorgchem.7b01294

This Article is brought to you for free and open access by the Department of Biological Sciences at LSU Digital Commons. It has been accepted for inclusion in Faculty Publications by an authorized administrator of LSU Digital Commons. For more information, please contact ir@lsu.edu. 


\title{
Synthesis and Characterization of Pt(II) Complexes with Pyridyl Ligands: Elongated Octahedral Ion Pairs and Other Factors Influencing ${ }^{1} \mathrm{H}$ NMR Spectra
}

\author{
Nerissa A. Lewis, Svetlana Pakhomova, Patricia A. Marzilli, ${ }^{\circledR}$ and Luigi G. Marzilli*i) \\ Department of Chemistry, Louisiana State University, Baton Rouge, Louisiana 70803, United States
}

Supporting Information

\begin{abstract}
Our goal is to develop convenient methods for obtaining trans- $\left[\mathrm{Pt}^{\mathrm{II}}(4-\mathrm{Xpy})_{2} \mathrm{Cl}_{2}\right]$ complexes applicable to 4 -substituted pyridines (4Xpy) with limited volatility and water solubility, properties typical of 4-Xpy, with $\mathrm{X}$ being a moiety targeting drug delivery. Treatment of cis$\left[\mathrm{Pt}^{\mathrm{II}}(\mathrm{DMSO})_{2} \mathrm{Cl}_{2}\right](\mathrm{DMSO}=$ dimethyl sulfoxide $)$ with 4-Xpy in acetonitrile allowed isolation of a new series of simple trans- $\left[\mathrm{Pt}^{\mathrm{II}}(4-\mathrm{Xpy})_{2} \mathrm{Cl}_{2}\right]$ complexes. A side product with very downfield $\mathrm{H} 2 / 6$ signals led to our synthesis of a series of new $\left[\mathrm{Pt}^{\mathrm{II}}(4-\mathrm{Xpy})_{4}\right] \mathrm{Cl}_{2}$ salts. For both series in $\mathrm{CDCl}_{3}$, the size of the $\mathrm{H} 2 / 6 \Delta \delta$ [coordinated minus "free" 4-Xpy H2/6 shift] decreased as 4-Xpy donor ability increased from 4-CNpy to 4-Me ${ }_{2} \mathrm{Npy}$. This finding can be attributed to the greater synergistic reduction in the inductive effect of the $\mathrm{Pt}$ (II) center with increased 4-Xpy donor ability. The high solubility of $\left[\mathrm{Pt}^{\mathrm{II}}(4-\mathrm{Xpy})_{4}\right] \mathrm{Cl}_{2}$ salts in $\mathrm{CDCl}_{3}$ (a solvent with low polarity) and the very downfield shift of the $\left[\mathrm{Pt}^{\mathrm{II}}(4-\mathrm{Xpy})_{4}\right] \mathrm{Cl}_{2} \mathrm{H} 2 / 6$ signals for the solutions

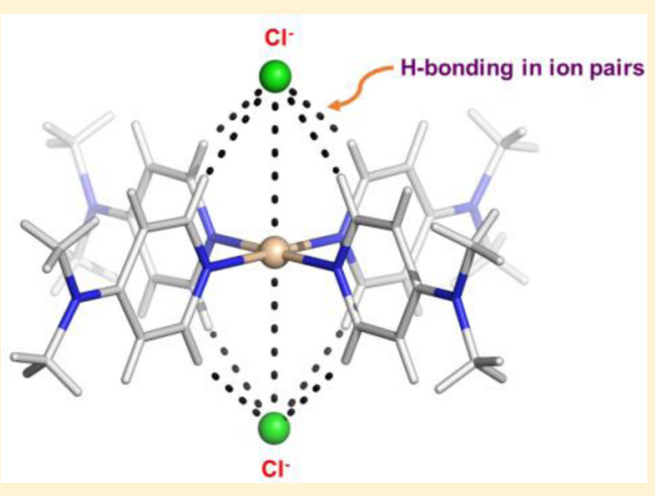
provide evidence for the presence of strong $\left\{\left[\mathrm{Pt}^{\mathrm{II}}(4-\mathrm{Xpy})_{4}\right]^{2+}, 2 \mathrm{Cl}^{-}\right\}$ion pairs that are stabilized by multiple $\mathrm{CH} \cdots \mathrm{Cl}$ contacts. This conclusion gains considerable support from $\left[\mathrm{Pt}^{\mathrm{II}}(4-\mathrm{Xpy})_{4}\right] \mathrm{Cl}_{2}$ crystal structures revealing that a chloride anion occupies a pseudoaxial position with nonbonding (py) $\mathrm{C}-\mathrm{H} \cdots \mathrm{Cl}$ contacts $(2.4-3.0 \AA)$. Evidence for (py) $\mathrm{C}-\mathrm{H} \cdots \mathrm{Y}$ contacts was obtained in NMR studies of $\left[\mathrm{Pt}^{\mathrm{II}}(4-\mathrm{Xpy})_{4}\right] \mathrm{Y}_{2}$ salts with $\mathrm{Y}$ counterions less capable of forming H-bonds than chloride ion. Our synthetic approaches and spectroscopic analysis are clearly applicable to other nonvolatile ligands.
\end{abstract}

\section{INTRODUCTION}

We have been exploring the metal-binding chemistry of strongly coordinating pyridyl ligands as one means of bioconjugation of targeting biological groups to create complexes with potential therapeutic or diagnostic utility. ${ }^{1}$ One highly useful synthon for our purposes is the $C_{2}$ symmetrical amine, 1-(4-pyridyl)piperazine (pyppzH, Figure 1 ). The piperazine $\mathrm{N}$ attached to the pyridyl ring increases the donor ability of the pyridyl ring $\mathrm{N}$, whereas the remote piperazine NH group can be used for linking chemistry. In this work we pursue fundamental $\mathrm{Pt}$ (II) chemistry relevant to the eventual use of such bioconjugated pyridyl ligands to prepare complexes having anticancer activity.

Cisplatin, cis- $\left[\mathrm{Pt}\left(\mathrm{NH}_{3}\right)_{2} \mathrm{Cl}_{2}\right]$, is one of the most effective chemotherapeutic agents being used in clinical therapy. ${ }^{2,3}$ Many closely related cis bifunctional analogues of cisplatin also show good anticancer activity. ${ }^{2,4-6}$ In contrast, the inactivity of the trans- $\left[\mathrm{Pt}\left(\mathrm{NH}_{3}\right)_{2} \mathrm{Cl}_{2}\right]$ isomer has led to a presumption that trans compounds are inactive. ${ }^{7-10}$ Historically, trans- $\left[\mathrm{PtL}_{2} \mathrm{Cl}_{2}\right]$ complexes have been neglected. In recent years, however, several types of platinum compounds with trans geometry have shown promising in vitro activity against several cancer cell lines, including some that are resistant to cisplatin. ${ }^{7-9,11-17}$ Among the recently studied trans platinum complexes, the iminoether complex trans- $\left[\mathrm{Pt}\left(E-\mathrm{HN}=\mathrm{C}\left(\mathrm{OCH}_{3}\right) \mathrm{CH}_{3}\right)_{2} \mathrm{Cl}_{2}\right]$ has been studied most intensively and has demonstrated significant activity against several cisplatin-resistant tumor cell lines. ${ }^{9,11,12,18}$ We propose that, whereas bulky ligands have been reported to decrease activity of cis bifunctional $\mathrm{Pt}$ (II) agents, bulky ligands are needed to allow trans bifunctional as well as monofunctional $\mathrm{Pt}(\mathrm{II})$ agents to form DNA adducts in which the DNA structure is distorted in such a way as to lead to cancer cell cytotoxicity. ${ }^{19-22}$

Because evidence exists that trans- $\left[\mathrm{PtL}_{2} \mathrm{Cl}_{2}\right]$ complexes with $\mathrm{L}=4$-substituted pyridyl ligands (4-Xpy) exhibit cancer cell cytotoxicity, ${ }^{16,17}$ we believe that 4-Xpy ligands have sufficient bulk to cause DNA distortions necessary for anticancer activity. Thus, we initiated an investigation of the preparation of trans$\left[\mathrm{Pt}^{\mathrm{II}}(4-\mathrm{Xpy})_{2} \mathrm{Cl}_{2}\right]$ complexes containing strongly coordinating pyridyl ligands such as 4-piperidinopyridine $\left(4-\left(\mathrm{CH}_{2}\right)_{5} \mathrm{Npy}\right.$, Figure 1). Syntheses reported for related complexes often yield the cis isomer, require harsh conditions (such as $100-150{ }^{\circ} \mathrm{C}$ or the use of concentrated $\mathrm{HCl}$ ), or depend on using aqueous conditions or volatile ligands. ${ }^{23-27}$ Such restrictions are not amenable to pyridine ligands containing sensitive linking groups, such as the sulfonamide group that we employ for bioconjugation. ${ }^{28}$

Received: May 19, 2017

Published: August 3, 2017 
<smiles>N#Cc1ccncc1</smiles>

(1)<smiles>COc1ccncc1</smiles>

4-MeOpy<smiles>FC(F)(F)c1ccncc1</smiles>

(2)<smiles>c1cc(N2CCCCC2)ccn1</smiles>

4- $\left(\mathrm{CH}_{2}\right)_{5} \mathrm{Npy}$

(5)

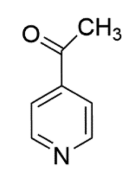

4-Mecopy

(6)

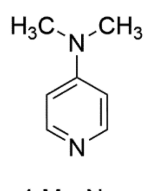

(4)

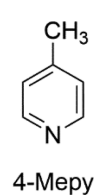

(7)<smiles>c1cc(N2CCNCC2)ccn1</smiles>

pyppzH
Figure 1. Pyridyl ligands (4-Xpy) used to synthesize complexes studied in the current work organized by donor ability to metals centers with the weakest donors in upper left and strongest donors in lower right. Also shown is the pyppzH synthon used in our bioconjugation approach. ${ }^{1}$ Bold numbers below the ligands are used to designate complexes prepared with the ligand having that number. trans- $\left[\mathrm{Pt}^{\mathrm{II}}(4-\mathrm{Xpy})_{2} \mathrm{Cl}_{2}\right]$ complexes are designated with these bold numbers alone, and $\left[\mathrm{Pt}^{\mathrm{II}}(4-\mathrm{Xpy})_{4}\right] \mathrm{Y}_{2}$ complexes are designated with these bold numbers plus a letter that identifies the counterion $\mathrm{Y}^{-}$, as follows: $\mathrm{Y}^{-}=\mathrm{Cl}^{-}(\mathbf{a}), \mathrm{PF}_{6}^{-}(\mathbf{b}), \mathrm{BF}_{4}^{-}(\mathbf{c}), \mathrm{BPh}_{4}^{-}(\mathbf{d})$, and $\mathrm{NO}_{3}^{-}$(e). For example, $\left[\mathrm{Pt}^{\mathrm{II}}(4-\mathrm{CNpy})_{4}\right] \mathrm{Cl}_{2}$ is numbered $\mathbf{1 a}$.

In the present study, we identify versatile approaches for preparing new trans- $\left[\mathrm{Pt}^{\mathrm{II}}(4-\mathrm{Xpy})_{2} \mathrm{Cl}_{2}\right]$ complexes. Our syntheses do not require high temperatures or rely on using volatile or water-soluble 4-Xpy. Because the binding of purine heterocycles to $\mathrm{Pt}(\mathrm{II})$ causes $\sim 1 \mathrm{ppm}$ downfield shift changes, we expected that large downfield ${ }^{1} \mathrm{H}$ NMR shift changes of the pyridyl ${ }^{1} \mathrm{H}$ NMR signals on binding to $\mathrm{Pt}(\mathrm{II})$ would guide us in our synthetic work. ${ }^{19-22,29,30}$ However, in our initial studies we were surprised to find only an $\sim 0.1 \mathrm{ppm}$ downfield shift change of the pyridyl $\mathrm{H} 2 / 6$ signal and even an upfield shift change of the $\mathrm{H} 3 / 5$ signal $(\sim 0.1 \mathrm{ppm})$ for ligands such as $4-\left(\mathrm{CH}_{2}\right)_{5} \mathrm{Npy}$. As an aid in improving methods for the synthesis and characterization of trans- $\left[\mathrm{Pt}^{\mathrm{II}}(4-\mathrm{Xpy})_{2} \mathrm{Cl}_{2}\right]$ complexes, we explored fundamental features of the NMR spectra of these complexes. The relatively few known cis/trans- $\left[\mathrm{Pt}(\mathrm{py})_{2} \mathrm{Y}_{2}\right]$ and $\left[\mathrm{Pt}\left(\mathrm{Xpy} \text { or } \mathrm{X}_{2} \mathrm{py}\right)_{4}\right] \mathrm{Y}_{2}$ complexes (mostly with $\mathrm{Y}=$ halide or $\mathrm{NCS}^{-}$and $\mathrm{X}=\mathrm{Me}$ ) contain ligands such as py, picolines (Mepy), and lutidines $\left(\mathrm{Me}_{2} \mathrm{py}\right)$ of similar donor ability as estimated by the respective $\mathrm{p} K_{\mathrm{a}}$ values of the protonated ligand, for example, $\mathrm{XpyH}^{+}$, falling within a very limited $\mathrm{pK}$ range. ${ }^{23,24,26,27,31-35}$ Also, NMR studies often were reported in different solvents. ${ }^{17}$ Thus, the dependence of the NMR signals on the properties of the complexes, such as the pyridyl ligand donor ability, was neither well-defined nor understood. Our use of 4-Xpy ligands with substituents at ring position 4 that vary widely in donor ability (e.g., 4-CNpy and 4- $\mathrm{Me}_{2} \mathrm{Npy}$, Figure 1) minimizes the through-space effect of $\mathrm{X}$ on the $\mathrm{H} 2 / 6$ ${ }^{1} \mathrm{H}$ NMR signal. This choice allowed us to assess the throughbond inductive effect passing through the $\mathrm{Pt}(\mathrm{II})$ center on the 4-Xpy $\mathrm{H} 2 / 6$ signals for a range of trans- $\left[\mathrm{Pt}^{\mathrm{II}}(4-\mathrm{Xpy})_{2} \mathrm{Cl}_{2}\right]$ complexes.

During our initial investigation of trans- $\left[\mathrm{Pt}(4-\mathrm{Xpy})_{2} \mathrm{Cl}_{2}\right]$ preparative procedures, some synthetic conditions gave side products with unprecedented, unusually downfield signals in $\mathrm{CDCl}_{3}$. We identified these as $\mathrm{H} 2 / 6$ signals of $\left[\mathrm{Pt}^{\mathrm{II}}(4-\right.$
Xpy $\left.)_{4}\right] \mathrm{Cl}_{2}$ side products. Published NMR data ${ }^{23,27}$ for $\left[\mathrm{Pt}^{\mathrm{II}}(4-\right.$ $\left.\mathrm{Xpy})_{4}\right] \mathrm{Cl}_{2}$ complexes are limited but are inconsistent with our results. To gain a comprehensive understanding of the NMR trends, we prepared a number of new $\left[\mathrm{Pt}^{\mathrm{II}}(4-\mathrm{Xpy})_{4}\right] \mathrm{Y}_{2}$ complexes with diverse 4-Xpy ligands and $\mathrm{Y}$ counterions. These NMR studies established that the very downfield shift position of the $\mathrm{H} 2 / 6$ pyridyl signals reflects the presence of strong $\left\{\left[\mathrm{Pt}^{\mathrm{II}}(4-\mathrm{Xpy})_{4}\right]^{2+}, 2 \mathrm{Cl}^{-}\right\}$ion pairs in which the $\mathrm{H} 2 / 6$ protons undoubtedly form $\mathrm{C}-\mathrm{H} \cdots \mathrm{Cl}$ contacts. This interpretation gains support from several crystal structures of some new $\left[\mathrm{Pt}^{\mathrm{II}}(4-\mathrm{Xpy})_{4}\right] \mathrm{Cl}_{2}$ complexes. The $\left[\mathrm{Pt}^{\mathrm{II}}(4-\mathrm{Xpy})_{4}\right]^{2+}$ cations in these crystals form part of elongated pseudo-octahedral structures with axial chloride ions that have contacts to the pyridyl ring $\mathrm{H} 2 / 6$ protons consistent with (py) $\mathrm{C}-\mathrm{H} \cdots \mathrm{Cl} \mathrm{H}$ bonding interactions. The distance of the chloride counterions to the $\mathrm{Pt}(\mathrm{II})$ center is usually a few tenths of an angstrom longer than the $\mathrm{Pt} \cdots \mathrm{Cl}$ contact distance of $\sim 3.5 \AA^{36,39}$ Such elongated pseudo-octahedral ion pairs explain the unusual NMR features of $\left[\mathrm{Pt}^{\mathrm{II}}(4-\mathrm{Xpy})_{4}\right] \mathrm{Cl}_{2}$ complexes, and also the resulting low charge of the $\left\{\left[\mathrm{Pt}^{\mathrm{II}}(4-\mathrm{Xpy})_{4}\right]^{2+}, 2 \mathrm{Cl}^{-}\right\}$ion pairs is consistent with the high solubility in $\mathrm{CDCl}_{3}$ of these salts containing $\left[\mathrm{Pt}^{\mathrm{II}}(4-\mathrm{Xpy})_{4}\right]^{2+}$ cations; such salts are otherwise expected to be poorly soluble.

\section{EXPERIMENTAL SECTION}

Starting Materials. Pyridine (py), 4-cyanopyridine (4-CNpy), 4trifluoromethylpyridine (4- $\mathrm{CF}_{3} \mathrm{py}$ ), 4-acetylpyridine (4-MeCOpy), 4methylpyridine (4-Mepy), 4-methoxypyridine (4-MeOpy), 4dimethylaminopyridine (4- $\left.\mathrm{Me}_{2} \mathrm{Npy}\right)$, 4-piperidinopyridine (4$\left.\left(\mathrm{CH}_{2}\right)_{5} \mathrm{Npy}\right), \mathrm{NaPF}_{6},\left[\mathrm{Et}_{4} \mathrm{~N}\right] \mathrm{BF}_{4}, \mathrm{NaBF}_{4},\left[\mathrm{Et}_{4} \mathrm{~N}\right] \mathrm{Cl}$, and $\left[\mathrm{Et}_{4} \mathrm{~N}\right] \mathrm{NO}_{3}$ were obtained from Sigma-Aldrich. cis- $\left[\mathrm{Pt}^{\mathrm{II}}(\mathrm{DMSO})_{2} \mathrm{Cl}_{2}\right]$ was prepared by a known method. ${ }^{38}$

NMR Measurements. ${ }^{1} \mathrm{H}$ NMR spectra were recorded on a 400 $\mathrm{MHz}$ Bruker spectrometer or on an Advance-III Prodigy $500 \mathrm{MHz}$ Bruker spectrometer. Peak positions are relative to 3-(trimethylsilyl)propionic-2,2,3,3- $d_{4}$ acid in $\mathrm{D}_{2} \mathrm{O}$, or solvent residual peak (DMSO- $d_{6}$, $\mathrm{CHD}_{2} \mathrm{CN}$, or $\mathrm{CHCl}_{3}$ ) with internal tetramethylsilane (TMS) as reference. All NMR data were processed with TopSpin and MestReNova software. For specific assignments of signals, please see Tables 1-3 and Supporting Information.

Mass Spectrometric Measurements. High-resolution mass spectra recorded on an Agilent 6210 ESI TOF LCMS mass spectrometer are reported in Supporting Information.

X-ray Data Collection and Structure Determination. Intensity data were collected at low temperature on a Bruker Kappa Apex-II

Table 1. H2/6 Chemical Shifts (ppm) and Shift Differences $(\Delta \delta, \mathrm{ppm})$ in $\mathrm{CDCl}_{3}$ at $25^{\circ} \mathrm{C}$ for 4 -Xpy Ligands $(5 \mathrm{mM})$ Both Free and in trans- $\left[\mathrm{Pt}(4-\mathrm{Xpy})_{2} \mathrm{Cl}_{2}\right]$ Complexes $^{a}(5 \mathrm{mM})$

\begin{tabular}{lcccc}
\multicolumn{1}{c}{$\mathrm{X}$} & $\mathrm{pK} K_{\mathrm{a}}$ & $4-\mathrm{Xpy}$ & trans-[$\left[\mathrm{Pt}(4-\mathrm{Xpy})_{2} \mathrm{Cl}_{2}\right]$ & $\mathrm{H} 2 / 6 \Delta \delta$ \\
$\mathrm{CN}$ & $2.10^{b}$ & 8.82 & 9.17 & 0.35 \\
$\mathrm{CF}_{3}$ & $2.46^{c}$ & 8.83 & 9.18 & 0.35 \\
$\mathrm{MeCO}$ & $3.51^{d}$ & 8.82 & 9.13 & 0.31 \\
$\mathrm{Me}^{e}$ & $5.98^{f}$ & 8.47 & 8.71 & 0.24 \\
$\mathrm{MeO}$ & $6.47^{g}$ & 8.45 & 8.69 & 0.24 \\
$\mathrm{Me}_{2} \mathrm{~N}$ & $9.61^{h}$ & 8.22 & 8.35 & 0.13 \\
$\left(\mathrm{CH}_{2}\right)_{5} \mathrm{~N}$ & $9.60^{i}$ & 8.23 & 8.34 & 0.11
\end{tabular}

$a_{\text {trans- }}\left[\mathrm{Pt}(\mathrm{py})_{2} \mathrm{Cl}_{2}\right]$, this study, $8.92 \mathrm{ppm}$; reported, $8.91 \mathrm{ppm}^{23}$ reported for cis-[ $\left.\mathrm{Pt}(\mathrm{py})_{2} \mathrm{Cl}_{2}\right], 8.74 \mathrm{ppm} .{ }^{23}{ }^{2} \mathrm{pK}_{\mathrm{a}}$ value from ref 52 . ${ }^{c}$ Estimated from the equation of the line: $y=-0.0884 x+9.0472$ (see Supporting Information, Figure S2). ${ }^{d} K_{\mathrm{a}}$ value from ref $53 .{ }^{e}$ Reported for trans-[Pt(4-Mepy) $\left.{ }_{2} \mathrm{Cl}_{2}\right], 8.69 \mathrm{ppm} ;{ }^{27}$ reported for cis-[Pt $(4-$ Mepy) $\left.{ }_{2} \mathrm{Cl}_{2}\right], 8.71 \mathrm{ppm}^{27} f_{\mathrm{pK}}$ value from ref $54 .{ }^{g} K_{\mathrm{a}}$ value from ref 55. ${ }^{h} \mathrm{p} K_{\mathrm{a}}$ value from ref $56 .{ }^{i} \mathrm{p} K_{\mathrm{a}}$ value from ref 1 . 
DUO CCD diffractometer fitted with an Oxford Cryostream cooler and graphite-monochromated $\mathrm{Mo} \mathrm{K} \alpha(\lambda=0.71073 \AA)$ radiation from an $\mathrm{I} \mu \mathrm{S}$ microfocus source with multilayer optics. Data reduction included absorption corrections by the multiscan method, with SADABS. ${ }^{39}$ All X-ray structures were determined by direct methods and difference Fourier techniques and refined by full-matrix leastsquares methods by using SHELXL2014 ${ }^{40}$ with $\mathrm{H}$ atoms in idealized positions.

General Syntheses of trans-[Pt" $\left.{ }^{\prime \prime}(4-\mathrm{Xpy})_{2} \mathrm{Y}_{2}\right]$ and $\left[\mathrm{Pt}^{\prime \prime}(4-\right.$ $\left.\mathrm{Xpy})_{4}\right]_{\mathrm{Y}_{2}}$ Complexes. The general synthetic method is illustrated in Scheme 1, and the numbering key for compounds in this study appears in Figure 1. Specific details on quantities used, yields, MS data, etc. can be found in Supporting Information.

Scheme 1. Synthesis of trans- $\left[\mathrm{Pt}^{\mathrm{II}}(4-\mathrm{Xpy})_{2} \mathrm{Cl}_{2}\right]$ and $\left[\mathrm{Pt}^{\mathrm{II}}(4-\right.$ $\left.\mathrm{Xpy})_{4}\right] \mathrm{Cl}_{2}$ Complexes, ${ }^{a}$ Showing Numbers for Product Complexes and the Numbering System for the 4-Xpy Ligands

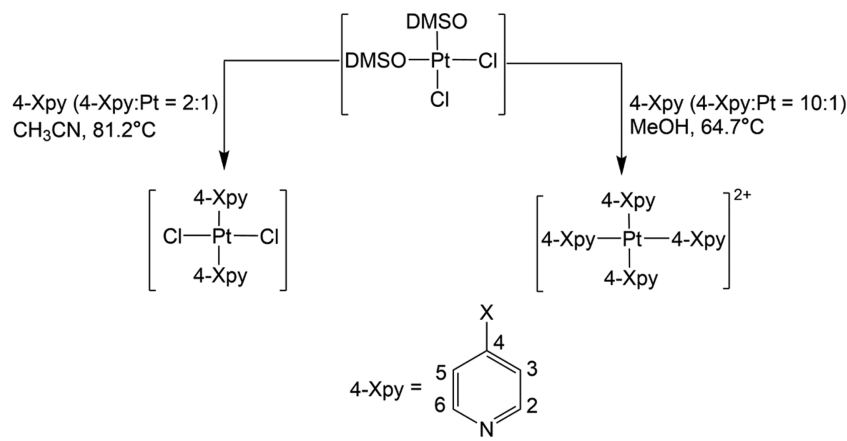

${ }^{a}$ Complexes that have numbers only are trans- $\left[\mathrm{Pt}(4-\mathrm{Xpy})_{2} \mathrm{Cl}_{2}\right]$ complexes. Numbers correlate with ligands $\left[\mathrm{X}=\mathrm{CN}(1) ; \mathrm{CF}_{3}(2)\right.$; $\mathrm{MeO}$ (3); $\mathrm{Me}_{2} \mathrm{~N}$ (4); $\left(\mathrm{CH}_{2}\right)_{5} \mathrm{~N}(5) ; \mathrm{MeCO}(6) ;$ and $\left.\mathrm{Me}(7)\right]$.

4-Xpy was added to an acetonitrile or methanol solution of cis$\left[\mathrm{Pt}^{\mathrm{II}}(\mathrm{DMSO})_{2} \mathrm{Cl}_{2}\right](42 \mathrm{mg}, 0.1 \mathrm{mmol}$, in $5 \mathrm{~mL})$ in a $2: 1$ or $10: 1$ (4$\mathrm{Xpy} / \mathrm{Pt}$ ) molar ratio, and the reaction mixture was heated at reflux for $24 \mathrm{~h}$. The precipitate that formed was collected on a filter, washed with acetonitrile or methanol and diethyl ether, and dried in air. The powder collected was then dissolved in $\mathrm{CHCl}_{3}(\sim 1-4 \mathrm{~mL})$, and diethyl ether $(\sim 10 \mathrm{~mL})$ was added until cloudiness was observed. After the mixture was left undisturbed $(\sim 10-15 \mathrm{~min}$ at room temperature), yellow or white products were collected on a filter, washed with diethyl ether, and dried in air. Although three trans$\left[\mathrm{Pt}^{\mathrm{II}}(4-\mathrm{Xpy})_{2} \mathrm{Cl}_{2}\right]$ complexes were previously reported $\left[\mathrm{X}=\mathrm{H}^{23}\right.$ $\mathrm{MeCO},{ }^{1+}$ and $\left.\mathrm{Me}^{24,27}\right]$, we prepared the three complexes by our synthetic method. ${ }^{1} \mathrm{H}$ NMR data at $25{ }^{\circ} \mathrm{C}$ in $\mathrm{CDCl}_{3}, \mathrm{CD}_{3} \mathrm{CN}$, deuterated dimethyl sulfoxide (DMSO- $d_{6}$ ), and $\mathrm{D}_{2} \mathrm{O}$ can be found in Table 1 and in the Supporting Information.
$\mathrm{X}$-ray quality crystals of trans- $\left[\mathrm{Pt}^{\mathrm{II}}(4-\mathrm{Xpy})_{2} \mathrm{Cl}_{2}\right]\left(\mathrm{X}=\mathrm{CF}_{3}(2), \mathrm{MeO}\right.$ (3), and $\left.\left(\mathrm{CH}_{2}\right)_{5} \mathrm{~N}(\mathbf{5})\right)$ and $\left[\mathrm{Pt}^{\mathrm{II}}(4-\mathrm{Xpy})_{4}\right] \mathrm{Cl}_{2}\left(\mathrm{X}=\mathrm{MeO}(\mathbf{3 a}), \mathrm{Me}_{2} \mathrm{~N}\right.$ (4a), $\left(\mathrm{CH}_{2}\right)_{5} \mathrm{~N}(\mathbf{5 a})$, and $\left.\mathrm{Me}(7 \mathbf{a})\right)$ were obtained by mixing equal volumes $(1 \mathrm{~mL})$ of 4 -Xpy and cis-[ $\left[\mathrm{Pt}^{\mathrm{II}}(\mathrm{DMSO})_{2} \mathrm{Cl}_{2}\right](5.3 \mathrm{mg}, 12.5$ $\mathrm{mM})$ in $2: 1$ or $10: 1(4-\mathrm{Xpy} / \mathrm{Pt})$ molar ratios in acetonitrile and allowing the mixture to stand at room temperature for 4-24 $\mathrm{d}$. When this room-temperature procedure was followed with $4-\mathrm{Me}_{2} \mathrm{Npy}$ (3.1 $\mathrm{mg}, 25 \mathrm{mM})$, the X-ray quality crystals collected after $8 \mathrm{~d}$ were the cis$\left[\mathrm{Pt}^{\mathrm{II}}\left(4-\mathrm{Me}_{2} \mathrm{Npy}\right)_{2} \mathrm{Cl}_{2}\right]$ isomer $\left(4^{\prime}\right)$.

The treatment of an aqueous solution $(3-5 \mathrm{~mL})$ of $\left[\mathrm{Pt}^{\mathrm{II}}(4-\right.$ $\left.\mathrm{Xpy})_{4}\right] \mathrm{Cl}_{2}\left(\mathrm{X}=\mathrm{MeO}(\mathbf{3 a}), \mathrm{Me}_{2} \mathrm{~N}(\mathbf{4 a}),\left(\mathrm{CH}_{2}\right)_{5} \mathrm{~N}(5 \mathbf{a})\right.$, and $\left.\mathrm{Me}(7 \mathbf{a})\right)$ $(0.1 \mathrm{mmol})$ with solid $\mathrm{NaPF}_{6}(170 \mathrm{mg}, 1.0 \mathrm{mmol}),\left[\mathrm{NEt}_{4}\right] \mathrm{BF}_{4}(220$ $\mathrm{mg}$, $1.0 \mathrm{mmol})$, or $\mathrm{NaBPh}_{4}(0.342 \mathrm{~g}$, $1.0 \mathrm{mmol})$ produced the respective $\left[\mathrm{Pt}^{\mathrm{II}}(4-\mathrm{Xpy})_{4}\right]\left(\mathrm{PF}_{6}\right)_{2}(\mathbf{3} \mathbf{b}-\mathbf{5 b}$ and $7 \mathbf{b}),\left[\mathrm{Pt}^{\mathrm{II}}(4-\mathrm{Xpy})_{4}\right]$ $\left(\mathrm{BF}_{4}\right)_{2}(3 \mathrm{c}-5 \mathrm{c}$ and $7 \mathrm{c})$, or $\left[\mathrm{Pt}^{\mathrm{II}}(4-\mathrm{Xpy})_{4}\right]\left(\mathrm{BPh}_{4}\right)_{2} \quad(\mathbf{2 d}$ and $4 \mathrm{~d})$ complexes as white solids, which were collected on a filter, washed with diethyl ether, and dried in air.

Alternate Synthesis of [Pt" $\left.(4-\mathrm{Xpy})_{4}\right] \mathrm{Y}_{2}$ Complexes $(\mathrm{X}=\mathrm{CN}$, $\mathrm{CF}_{3}, \mathrm{MeCO}, \mathrm{MeOpy}$, or $\mathrm{Me}_{2} \mathrm{~N} ; \mathrm{Y}=\mathrm{NO}_{3}^{-}, \mathrm{PF}_{6}{ }^{-}$, or $\left.\mathrm{BF}_{4}^{-}\right)$. The general synthetic method for $\left[\mathrm{Pt}^{\mathrm{II}}(4-\mathrm{Xpy})_{4}\right] \mathrm{Y}_{2}$ complexes was not successful with weak donor ligands (4-CNpy, 4-CF 3 py, and 4MeCOpy). The desired $\left[\mathrm{Pt}^{\mathrm{II}}(4-\mathrm{Xpy})_{4}\right] \mathrm{Y}_{2}$ complexes were prepared by an alternate method. Specific details on quantities used, yields, MS data, etc. can be found in Supporting Information. In this alternate method, a methanol solution $(5 \mathrm{~mL})$ of $c i s$ - $\left[\mathrm{Pt}^{\mathrm{II}}(\mathrm{DMSO})_{2} \mathrm{Cl}_{2}\right](42 \mathrm{mg}$, $0.1 \mathrm{mmol}$ ) was first treated with $\mathrm{AgNO}_{3}(29 \mathrm{mg}, 0.17 \mathrm{mmol})$ and then with 4-CNpy, 4-CF 3 py, and 4-MeCOpy in a 40:1 (4-Xpy/Pt) molar ratio. The moderate and strong donor ligands, 4-Mepy, 4-MeOpy, and $4-\mathrm{Me}_{2} \mathrm{Npy}$, were used to prepare $\left[\mathrm{Pt}^{\mathrm{II}}(4-\mathrm{Xpy})_{4}\right]\left(\mathrm{NO}_{3}\right)_{2}$ complexes $(7 \mathbf{e}, 3 \mathbf{e}$, and $4 \mathbf{e})$ for comparison to the analogues having weak 4-Xpy donors. The reaction mixture was heated at reflux for $24 \mathrm{~h}$; after $\sim 10$ min a white precipitate (presumed to be $\mathrm{AgCl}$ ) formed, and the gray precipitate produced was collected on a filter and then suspended in acetonitrile $(2-4 \mathrm{~mL})$ to dissolve the desired $\left[\mathrm{Pt}^{\mathrm{II}}(4-\mathrm{Xpy})_{4}\right]\left(\mathrm{NO}_{3}\right)_{2}$ salt. The mixture was filtered (to remove $\mathrm{AgCl}$ ), and ether was added to the filtrate to the point of cloudiness $(\sim 10-15 \mathrm{~mL})$. The white precipitate formed $\left\{\left[\mathrm{Pt}{ }^{\mathrm{II}}(4-\mathrm{CNpy})_{4}\right]\left(\mathrm{NO}_{3}\right)_{2}(\mathbf{1 e}),\left[\mathrm{Pt}^{\mathrm{II}}\left(4-\mathrm{CF}_{3} \mathrm{py}\right)_{4}\right]-\right.$ $\left.\left(\mathrm{NO}_{3}\right)_{2}(\mathbf{2 e}),\left[\mathrm{Pt} \mathrm{Pt}^{\mathrm{II}}(4-\mathrm{MeCOpy})_{4}\right]\left(\mathrm{NO}_{3}\right)_{2}(\mathbf{6 e})\right\}$ was collected on a filter, washed with methanol and diethyl ether, and dried in air. For all of these products, ${ }^{1} \mathrm{H}$ NMR spectra (in $\mathrm{CD}_{3} \mathrm{CN}$ at $25{ }^{\circ} \mathrm{C}$ ) recorded both upon dissolution and subsequently contained only one set of signals.

The treatment of an aqueous solution $(3-5 \mathrm{~mL})$ of $\left[\mathrm{Pt}^{\mathrm{II}}(4-\right.$ $\left.\mathrm{Xpy})_{4}\right]\left(\mathrm{NO}_{3}\right)_{2}\left(\mathrm{X}=\mathrm{CN}(\mathbf{1 e}), \mathrm{CF}_{3}(\mathbf{2 e})\right.$, or $\left.\mathrm{MeCO}(\mathbf{6 e})\right)(0.1 \mathrm{mmol})$ with solid $\mathrm{NaPF}_{6}(170 \mathrm{mg}, 1.0 \mathrm{mmol})$ or $\mathrm{NaBF}_{4}(110 \mathrm{mg}, 1.0 \mathrm{mmol})$ produced the respective $\left[\mathrm{Pt}^{\mathrm{II}}(4-\mathrm{Xpy})_{4}\right]\left(\mathrm{PF}_{6}\right)_{2}(\mathbf{1 b}, \mathbf{2} \mathbf{b}$, and $\mathbf{6 b})$ or $\left[\mathrm{Pt}^{\mathrm{II}}(4-\mathrm{Xpy})_{4}\right]\left(\mathrm{BF}_{4}\right)_{2}(\mathbf{1 c}, 2 \mathrm{c}$, and $\mathbf{6 c})$ as white solids, which were collected on a filter, washed with water and diethyl ether, and dried in air. $\left[\mathrm{Pt}^{\mathrm{II}}(4-\mathrm{Xpy})_{4}\right]\left(\mathrm{PF}_{6}\right)_{2}$ and $\left[\mathrm{Pt}^{\mathrm{II}}(4-\mathrm{Xpy})_{4}\right]\left(\mathrm{BF}_{4}\right)_{2}[\mathrm{X}=\mathrm{MeO}(3 \mathbf{b}$ and $3 c), \mathrm{Me}_{2} \mathrm{~N}$ (4b and $4 \mathrm{c}$ ), or $\mathrm{Me}(7 \mathrm{~b}$ and $\left.7 \mathrm{c})\right]$ were prepared as described above by using solid $\left[\mathrm{NEt}_{4}\right] \mathrm{BF}_{4} \cdot{ }^{1} \mathrm{H} \mathrm{NMR}$ data in $\mathrm{CDCl}_{3}$,

Table 2. H2/6 Chemical Shifts (ppm) and Shift Differences $\left(\Delta \delta\right.$, ppm) in $\mathrm{CDCl}_{3}$ at $25{ }^{\circ} \mathrm{C}$ for 4 -Xpy Ligands $(5 \mathrm{mM}) \mathrm{Both}$ Free and in $\left[\mathrm{Pt}(4-\mathrm{Xpy})_{4}\right] \mathrm{Y}_{2}$ Complexes $(5 \mathrm{mM})$

\begin{tabular}{|c|c|c|c|c|c|c|c|c|c|c|}
\hline \multirow[b]{2}{*}{$\mathrm{X} / \mathrm{Y}$} & \multicolumn{6}{|c|}{$\mathrm{H} 2 / 6$} & \multicolumn{4}{|c|}{$\mathrm{H} 2 / 6 \Delta \delta$} \\
\hline & $\mathrm{p} K_{\mathrm{a}}$ & free & $\mathrm{Cl}^{-}$ & $\mathrm{NO}_{3}^{-}$ & $\mathrm{BF}_{4}^{-}$ & $\mathrm{PF}_{6}^{-}$ & $\mathrm{Cl}^{-}$ & $\mathrm{NO}_{3}^{-}$ & $\mathrm{BF}_{4}^{-}$ & $\mathrm{PF}_{6}^{-}$ \\
\hline $\mathrm{CN}$ & $2.10^{a}$ & 8.82 & $10.66^{b}$ & ins & ins & ins & $1.84^{b}$ & ins & ins & ins \\
\hline $\mathrm{CF}_{3}{ }^{c}$ & $2.46^{d}$ & 8.83 & $10.74^{b}$ & 9.97 & 9.76 & ins & $1.91^{b}$ & 1.14 & 0.93 & ins \\
\hline $\mathrm{MeCO}$ & $3.51^{e}$ & 8.82 & $10.60^{b}$ & ins & 9.62 & ins & $1.78^{b}$ & ins & 0.80 & ins \\
\hline $\mathrm{Me}$ & $5.98^{f}$ & 8.47 & $10.02^{g}$ & 9.36 & 9.11 & 8.86 & $1.55^{g}$ & 0.89 & 0.64 & 0.39 \\
\hline $\mathrm{MeO}$ & $6.47^{h}$ & 8.45 & $9.93^{g}$ & 9.24 & 9.04 & 8.79 & $1.48^{g}$ & 0.79 & 0.59 & 0.34 \\
\hline $\mathrm{Me}_{2} \mathrm{~N}^{i}$ & $9.61^{j}$ & 8.22 & $9.07^{g}$ & 8.66 & 8.49 & 8.24 & $0.85^{g}$ & 0.44 & 0.27 & 0.02 \\
\hline$\left(\mathrm{CH}_{2}\right)_{5} \mathrm{~N}$ & $9.60^{1 k}$ & 8.23 & $9.00^{g}$ & & 8.44 & 8.22 & $0.77^{g}$ & & 0.21 & -0.01 \\
\hline
\end{tabular}

${ }^{a} \mathrm{pK}$ value from ref $52 .{ }^{b}$ Contains $50 \mathrm{mM}\left[\mathrm{Et}_{4} \mathrm{~N}\right] \mathrm{Cl} .{ }^{c}\left[\mathrm{Pt}\left(4-\mathrm{CF}_{3} \mathrm{py}\right)_{4}\right]\left(\mathrm{BPh}_{4}\right)_{2}$ is insoluble in $\mathrm{CDCl}_{3}$ at $25{ }^{\circ} \mathrm{C} .{ }^{d}$ Estimated from the equation of the line: $y=-0.0884 x+9.0472$ (see Supporting Information, Figure S2). ${ }^{e} K_{\mathrm{a}}$ value from ref $53 .{ }_{\mathrm{p}} K_{\mathrm{a}}$ value from ref $54 .{ }^{g} \mathrm{Contains} 40 \mathrm{mM}\left[\mathrm{Et} \mathrm{t}_{4} \mathrm{~N}\right] \mathrm{Cl}$. ${ }^{h} K_{\mathrm{a}}$ value from ref 55. ${ }^{i}\left[\mathrm{Pt}\left(4-\mathrm{Me}_{2} \mathrm{Npy}\right)_{4}\right]\left(\mathrm{BPh}_{4}\right)_{2}, 7.28 \mathrm{ppm} .{ }^{j} K_{\mathrm{a}}$ value from ref $56 .{ }_{\mathrm{p}} K_{\mathrm{a}}$ value from ref 1. 
Table 3. $\mathrm{H} 2 / 6$ Chemical Shifts (ppm) and Shift Differences $\left(\Delta \delta\right.$, ppm) in $\mathrm{CD}_{3} \mathrm{CN}$ at $25{ }^{\circ} \mathrm{C}$ for 4 -Xpy Ligands (5 mM) Both Free and in $\left[\operatorname{Pt}(4-\mathrm{Xpy})_{4}\right] \mathrm{Y}_{2}$ Complexes $(5 \mathrm{mM})$

\begin{tabular}{|c|c|c|c|c|c|c|c|c|c|c|}
\hline \multirow[b]{2}{*}{$\mathrm{X} / \mathrm{Y}$} & \multirow[b]{2}{*}{$\mathrm{p} K_{\mathrm{a}}$} & \multicolumn{5}{|c|}{$\mathrm{H} 2 / 6$} & \multicolumn{4}{|c|}{$\mathrm{H} 2 / 6 \Delta \delta$} \\
\hline & & free & $\mathrm{Cl}^{-}$ & $\mathrm{NO}_{3}^{-}$ & $\mathrm{BF}_{4}^{-}$ & $\mathrm{PF}_{6}^{-}$ & $\mathrm{Cl}^{-}$ & $\mathrm{NO}_{3}^{-}$ & $\mathrm{BF}_{4}^{-}$ & $\mathrm{PF}_{6}^{-}$ \\
\hline $\mathrm{CN}$ & $2.10^{a}$ & 8.78 & $10.50^{b}$ & 9.31 & 9.01 & 8.93 & $1.72^{b}$ & 0.53 & 0.23 & 0.15 \\
\hline $\mathrm{CF}_{3}{ }^{c}$ & $2.46^{d}$ & 8.82 & $10.59^{b}$ & 9.45 & 9.07 & 9.02 & $1.77^{b}$ & 0.63 & 0.25 & 0.20 \\
\hline $\mathrm{MeCO}$ & $3.51^{e}$ & 8.77 & $10.51^{b}$ & 9.28 & 8.97 & 8.95 & $1.74^{b}$ & 0.51 & 0.20 & 0.18 \\
\hline $\mathrm{Me}$ & $5.98^{f}$ & 8.41 & $9.84^{g}$ & 8.63 & 8.50 & 8.48 & $1.43^{g}$ & 0.22 & 0.09 & 0.07 \\
\hline $\mathrm{MeO}$ & $6.47^{h}$ & 8.38 & $9.83^{g}$ & 8.59 & 8.40 & 8.37 & $1.45^{g}$ & 0.21 & 0.02 & -0.01 \\
\hline $\mathrm{Me}_{2} \mathrm{~N}^{i, j}$ & $9.61^{k}$ & 8.13 & $8.75^{g}$ & 8.00 & 7.91 & 7.90 & $0.62^{g}$ & -0.13 & -0.22 & -0.23 \\
\hline$\left(\mathrm{CH}_{2}\right)_{5} \mathrm{~N}$ & $9.60^{l}$ & 8.13 & $8.74^{g}$ & & 7.88 & 7.85 & $0.61^{g}$ & & -0.25 & -0.28 \\
\hline
\end{tabular}

${ }^{a} \mathrm{pK}$ a value from ref 52. ${ }^{b}$ Contains $50 \mathrm{mM}\left[\mathrm{Et}_{4} \mathrm{~N}\right] \mathrm{Cl} .{ }^{c}\left[\mathrm{Pt}\left(4-\mathrm{CF}_{3} \mathrm{py}\right)_{4}\right]\left(\mathrm{BPh}_{4}\right)_{2}, 9.01 \mathrm{ppm} .{ }^{d}$ Estimated from the equation of the line: $y=-0.0884 x+$ 9.0472 (see Supporting Information, Figure S2). ${ }_{\mathrm{p}} K_{\mathrm{a}}$ value from ref $53 .{ }_{\mathrm{p} K} K_{\mathrm{a}}$ value from ref $54 .{ }^{g}$ Contains $40 \mathrm{mM}$ [Et $\left.\mathrm{Et}_{4} \mathrm{~N}\right] \mathrm{Cl} .{ }^{h} \mathrm{p} K_{\mathrm{a}}$ value from ref 55 . ${ }^{i}$ Data collected for $\left[\mathrm{Pt}\left(4-\mathrm{Me}_{2} \mathrm{Npy}\right)_{4}\right] \mathrm{Cl}_{2}$ (without $\left.\left[\mathrm{Et}_{4} \mathrm{~N}\right] \mathrm{Cl}\right), 8.42 \mathrm{ppm} .{ }^{j}\left[\mathrm{Pt}\left(4-\mathrm{Me}_{2} \mathrm{Npy}\right)_{4}\right]\left(\mathrm{BPh}_{4}\right)_{2}, 7.88 \mathrm{ppm} .{ }_{\mathrm{p}} K_{\mathrm{a}}$ value from ref $56 .{ }_{\mathrm{p}} K_{\mathrm{a}}$ value from ref 1 .

DMSO- $d_{6}, \mathrm{D}_{2} \mathrm{O}$, and $\mathrm{CD}_{3} \mathrm{CN}$ at $25^{\circ} \mathrm{C}$ appear in Tables 2 and 3 and in Supporting Information.

[Et $\left.{ }_{4} \mathrm{~N}\right] \mathrm{Cl}$ Addition to [Pt"(4-Mepy $\left.)_{4}\right]\left(\mathrm{NO}_{3}\right)_{2}$, [Pt" (4-Mepy) $\left.)_{4}\right]-$ $\left(\mathrm{BF}_{4}\right)_{2}$, and $\left[\mathrm{Pt}^{\prime \prime}(4-\mathrm{Xpy})_{4}\right]\left(\mathrm{PF}_{6}\right)_{2}$ Complexes $\left(\mathrm{X}=\mathrm{Me}, \mathrm{MeO}, \mathrm{Me}_{2} \mathrm{~N}\right.$, and $\left.\left(\mathrm{CH}_{2}\right)_{5} \mathrm{~N}\right)$ in $\mathrm{CDCl}_{3}$ or DMSO-d $d_{6}$. The effect of $\left[\mathrm{Et}_{4} \mathrm{~N}\right] \mathrm{Cl}$ on a 5 $\mathrm{mM}$ solution of the desired $\left[\mathrm{Pt}^{\mathrm{II}}(4-\mathrm{Xpy})_{4}\right] \mathrm{Y}_{2}$ complex in $\mathrm{CDCl}_{3}$ (except for $\left[\mathrm{Pt}^{\mathrm{II}}\left(4-\mathrm{Me}_{2} \mathrm{Npy}\right)_{4}\right]\left(\mathrm{PF}_{6}\right)_{2}$, which was poorly soluble) or DMSO- $d_{6}$ was studied with a $600 \mathrm{mM}$ stock solution of $\left[\mathrm{Et}_{4} \mathrm{~N}\right] \mathrm{Cl}$ prepared from a $5 \mathrm{mM}$ solution of the complex to keep the complex concentration constant throughout the experiment. ${ }^{1} \mathrm{H}$ NMR spectra were recorded for each solution $\left(1-125 \mathrm{mM}\right.$ in $\left.\left[\mathrm{Et}_{4} \mathrm{~N}\right] \mathrm{Cl}\right)$ after the addition of each $\left[\mathrm{Et}_{4} \mathrm{~N}\right] \mathrm{Cl}$ aliquot. As the $\mathrm{Cl}^{-}$concentration was increased from $0-125 \mathrm{mM}$, a downfield shift $(0.05 \mathrm{ppm})$ was observed for the residual $\mathrm{CHCl}_{3}$ signal (from 7.2629 to $7.3080 \mathrm{ppm}$ ) relative to TMS as reference. To account for this shift change, shifts of all peaks were adjusted accordingly.

$\left[\mathrm{Et}_{4} \mathrm{~N}\right] \mathrm{Cl}$ Addition to $\left[\mathrm{Pt}(4-\mathrm{Xpy})_{4}\right]\left(\mathrm{NO}_{3}\right)_{2}$ in $\mathrm{CDCl}_{3}$ or $\mathrm{CD}_{3} \mathrm{CN}$. NMR tubes containing enough solid $\left[\mathrm{Pt}^{\mathrm{II}}(4-\mathrm{Xpy})_{4}\right]\left(\mathrm{NO}_{3}\right)_{2}(\mathrm{X}=\mathrm{CN}$ or $\left.\mathrm{CF}_{3}\right)$ and $\mathrm{CDCl}_{3}(600 \mu \mathrm{L})$ to make $5 \mathrm{mM}$ solutions in $\mathrm{CDCl}_{3}$ at 25 ${ }^{\circ} \mathrm{C}$ were treated with enough $\left[\mathrm{Et}_{4} \mathrm{~N}\right] \mathrm{Cl}(12.4 \mathrm{mg})$ to make a $125 \mathrm{mM}$ solution. The two salts dissolved rapidly, and ${ }^{1} \mathrm{H}$ NMR spectra were recorded for each solution within a few minutes and over a period of 9 d. Because of the low solubility of these $\left[\mathrm{Pt}^{\mathrm{II}}(4-\mathrm{Xpy})_{4}\right]\left(\mathrm{NO}_{3}\right)_{2}(\mathrm{X}=$ $\mathrm{CN}$ or $\mathrm{CF}_{3}$ ) salts in $\mathrm{CDCl}_{3}$, we studied them (as well as nitrate salts having moderate and good donor 4-Xpy ligands) in $\mathrm{CD}_{3} \mathrm{CN}$, by recording ${ }^{1} \mathrm{H}$ NMR spectra soon after and $24 \mathrm{~h}$ after addition of 10 molar equiv of $\left[\mathrm{Et}_{4} \mathrm{~N}\right] \mathrm{Cl}(5 \mathrm{mg})$.

[ $\left.\mathrm{Et}_{4} \mathrm{~N}\right] \mathrm{Cl}$ Addition to [Pt" $\left.(4-\mathrm{Xpy})_{4}\right] \mathrm{Y}_{2}$ Complexes in $\mathrm{D}_{2} \mathrm{O}$ or DMSO- $d_{6}$. Solutions $(5 \mathrm{mM})$ of selected $\left[\mathrm{Pt}^{\mathrm{II}}(4-\mathrm{Xpy})_{4}\right] \mathrm{Y}_{2}$ complexes in $\mathrm{D}_{2} \mathrm{O}$ or DMSO- $d_{6}(600 \mu \mathrm{L})$ at $25{ }^{\circ} \mathrm{C}$ were treated with 10 molar equiv of $\left[\mathrm{Et}_{4} \mathrm{~N}\right] \mathrm{Cl}(5 \mathrm{mg})$ for $\left[\mathrm{Pt}^{\mathrm{II}}(4-\mathrm{Xpy})_{4}\right]\left(\mathrm{NO}_{3}\right)_{2}$ salts or with 8 molar equiv of $\left[\mathrm{Et}_{4} \mathrm{~N}\right] \mathrm{Cl}(4 \mathrm{mg})$ for $\left[\mathrm{Pt}^{\mathrm{II}}(4-\mathrm{Xpy})_{4}\right] \mathrm{Cl}_{2}$ salts; each solution was examined by ${ }^{1} \mathrm{H}$ NMR spectroscopy.

\section{RESULTS AND DISCUSSION}

Synthesis. As illustrated in Scheme 1, the treatment of cis$\left[\mathrm{Pt}^{\mathrm{II}}(\mathrm{DMSO})_{2} \mathrm{Cl}_{2}\right]$ in acetonitrile with 2 equiv of 4 -Xpy afforded $26-51 \%$ yields of solids containing pure trans$\left[\mathrm{Pt}^{\mathrm{II}}(4-\mathrm{Xpy})_{2} \mathrm{Cl}_{2}\right]$ complexes $\left(\mathrm{X}=\mathrm{CN}, \mathrm{CF}_{3}, \mathrm{MeCO}, \mathrm{Me}\right.$, $\mathrm{MeO}$, and $\left.\left(\mathrm{CH}_{2}\right)_{5} \mathrm{~N}\right)$. However, when methanol was used as the solvent, mixtures of cis and trans isomers of $\left[\mathrm{Pt}^{\mathrm{II}}(4-\right.$ $\mathrm{Xpy})_{2} \mathrm{Cl}_{2}$ ] were obtained, as could be deduced from reported NMR data ${ }^{23,24,27}$ on a few $\left[\mathrm{Pt}^{\mathrm{II}}(4-\mathrm{Xpy})_{2} \mathrm{Cl}_{2}\right]$ complexes; in addition, spectra showed small signals with very downfield shifts that did not correspond to those in any literature reports.

When a methanol solution of cis- $\left[\mathrm{Pt}^{\mathrm{II}}(\mathrm{DMSO})_{2} \mathrm{Cl}_{2}\right]$ was treated instead with 10 equiv of relatively good 4-Xpy donor ligands $\left(\mathrm{X}=\mathrm{Me}, \mathrm{MeO}, \mathrm{Me}_{2} \mathrm{~N}\right.$, and $\left.\left(\mathrm{CH}_{2}\right)_{5} \mathrm{~N}\right),\left[\mathrm{Pt}^{\mathrm{II}}(4-\right.$ $\left.\mathrm{Xpy})_{4}\right] \mathrm{Cl}_{2}$ complexes were formed in $49-84 \%$ yields. These dicationic complexes were very soluble in $\mathrm{CDCl}_{3}$ and exhibited the unusual, very downfield minor H2/6 NMR signals observed in reactions with only 2 equiv of 4 -Xpy. Factors leading to the high solubility and very downfield shifts are discussed below.

To expand the range of 4-Xpy basicity and donor ability in the $\left[\mathrm{Pt}^{\mathrm{II}}(4-\mathrm{Xpy})_{4}\right] \mathrm{Y}_{2}$ series, a modified synthetic approach was employed. When 4-CNpy, 4- $\mathrm{CF}_{3}$ py, or $\mathrm{MeCO}$ was added to a methanol solution of cis-[ $\left.\mathrm{Pt}^{\mathrm{II}}(\mathrm{DMSO})_{2} \mathrm{Cl}_{2}\right]$ in a 40:1 (4-Xpy/ $\mathrm{Pt}$ ) molar ratio and the solution heated to reflux in the presence of $\mathrm{AgNO}_{3}$, the respective $\left[\mathrm{Pt}{ }^{\mathrm{II}}(4-\mathrm{Xpy})_{4}\right]\left(\mathrm{NO}_{3}\right)_{2}$ complexes were obtained in $68 \%, 87 \%$, or $76 \%$ yields. Aqueous solutions of $\left[\mathrm{Pt}^{\mathrm{II}}(4-\mathrm{Xpy})_{4}\right]\left(\mathrm{NO}_{3}\right)_{2}\left(\mathrm{X}=\mathrm{CN}(\mathbf{1 e}), \mathrm{CF}_{3}(\mathbf{2 e})\right.$, and $\mathrm{MeCO}$ (6e) and $\left[\mathrm{Pt}^{\mathrm{II}}(4-\mathrm{Xpy})_{4}\right] \mathrm{Cl}_{2}\left(\mathrm{X}=\mathrm{MeO}(3 \mathrm{a}), \mathrm{Me}_{2} \mathrm{~N}\right.$ (4a), $\left(\mathrm{CH}_{2}\right)_{5} \mathrm{~N}(\mathbf{5 a})$, and $\left.\mathrm{Me}(7 \mathbf{a})\right)(0.1 \mathrm{mmol})$ were then treated with solid $\mathrm{NaPF}_{6}, \mathrm{NaBF}_{4}$, or $\left[\mathrm{Et}_{4} \mathrm{~N}\right] \mathrm{BF}_{4}$ to produce the respective $\left[\mathrm{Pt}^{\mathrm{II}}(4-\mathrm{Xpy})_{4}\right]\left(\mathrm{PF}_{6}\right)_{2}(\mathbf{1 b}-\mathbf{7 b})$ or $\left[\mathrm{Pt}^{\mathrm{II}}(4-\mathrm{Xpy})_{4}\right]$ $\left(\mathrm{BF}_{4}\right)_{2}(\mathbf{1 c}-7 \mathrm{c})$ complexes.

Structural Results. Overall Aspects. Crystal data and details of the structural refinement for complexes 2, 3, 4', 5, $\mathbf{3 a}-\mathbf{5 a}$, and $7 \mathbf{a}$ are summarized in Supporting Information; ORTEP plots for these compounds are shown in Figures 2-4, along with the atom-numbering schemes used to describe the solid-state data. Selected bond lengths and bond angles are presented in Tables 4-6. In the trans- $\left[\mathrm{Pt}^{\mathrm{II}}(4-\mathrm{Xpy})_{2} \mathrm{Cl}_{2}\right]$ complexes $(2,3$, and 5$)$, the $\mathrm{Pt}^{\mathrm{II}}$ metal center has two trans chloro ligands and two N-bonded pyridyl ligands (Figure 2).

$\left[\mathrm{Pt}\right.$ (1)-Xpy $\left.{ }_{2} \mathrm{Cl}_{2}\right]$ Structures. Even though the 4-Xpy ligands differ considerably in donor potential, the values of the $\mathrm{Pt}-\mathrm{N}, \mathrm{Pt}-\mathrm{Cl}, \mathrm{C} 1-\mathrm{N} 1$, and $\mathrm{C} 5-\mathrm{N} 1$ bond distances and the $\mathrm{Pt}-\mathrm{N}-\mathrm{C}$ and $\mathrm{C}-\mathrm{N}-\mathrm{C}$ bond angles for trans- $\left[\mathrm{Pt}^{\mathrm{II}}(4-\right.$ $\left.\mathrm{Xpy})_{2} \mathrm{Cl}_{2}\right], \mathrm{X}=\mathrm{CF}_{3}$ (2), $\mathrm{MeO}(3)$, and $\left(\mathrm{CH}_{2}\right)_{5} \mathrm{~N}$ (5) (Table 4) and for cis- $\left[\mathrm{Pt}^{\mathrm{II}}\left(4-\mathrm{Me}_{2} \mathrm{Npy}\right)_{2} \mathrm{Cl}_{2}\right]\left(4^{\prime}\right)$ (Table 5) are not significantly different. In addition, no significant differences were observed in the metrics of the molecular structure of these new structures with those reported for trans- $\left[\mathrm{Pt}^{\mathrm{II}}(\mathrm{py})_{2} \mathrm{Cl}_{2}\right]^{41}$ and cis- $\left[\mathrm{Pt}^{\mathrm{II}}(\mathrm{py})_{2} \mathrm{Cl}_{2}\right]^{41}$ or for trans- $\left[\mathrm{Pt}^{\mathrm{II}}(4-\mathrm{Mepy})_{2} \mathrm{Cl}_{2}\right]^{24}$ and cis- $\left[\mathrm{Pt}^{\mathrm{II}}(4-\mathrm{Mepy})_{2} \mathrm{Cl}\right] .{ }^{24}$ Thus, these structural parameters are not significantly influenced by either the basicity of 4-Xpy or the cis or trans geometry of the complex. In the $\left[\mathrm{Pt}^{\mathrm{II}}(4-\right.$ $\mathrm{Xpy})_{2} \mathrm{Cl}_{2}$ ] complexes studied here, the dihedral angle between the plane of the 4-substituted pyridine ligands and the coordination plane (a feature we call canting) is $\sim 50^{\circ}$ (see Supporting Information).

$\left[\mathrm{Pt}^{\prime \prime}(4-\mathrm{Xpy})_{4}\right] \mathrm{Cl}_{2}$ Structures. ORTEP plots for the cations of $\left[\mathrm{Pt}^{\mathrm{II}}(4-\mathrm{MeOpy})_{4}\right] \mathrm{Cl}_{2}$ (3a), $\left[\mathrm{Pt}^{\mathrm{II}}\left(4-\mathrm{Me}_{2} \mathrm{Npy}_{4}\right] \mathrm{Cl}_{2}\right.$ (4a), $\left[\mathrm{Pt}^{\mathrm{II}}\left(4-\left(\mathrm{CH}_{2}\right)_{5} \mathrm{Npy}\right)_{4}\right] \mathrm{Cl}_{2}(5 \mathrm{a})$, and $\left[\mathrm{Pt}^{\mathrm{II}}\left(4-\mathrm{Mepy}_{4}\right] \mathrm{Cl}_{2}(7 \mathbf{a})\right.$ 
2

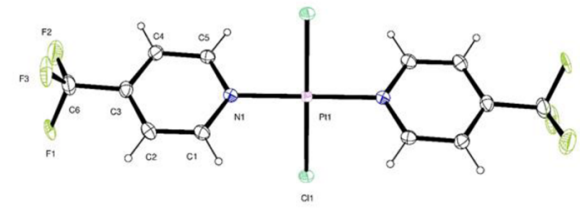

3

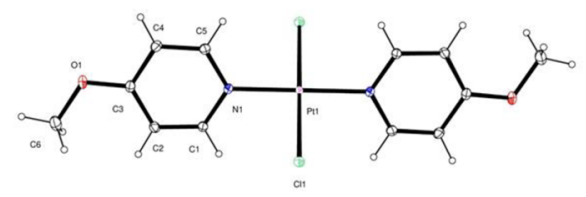

5

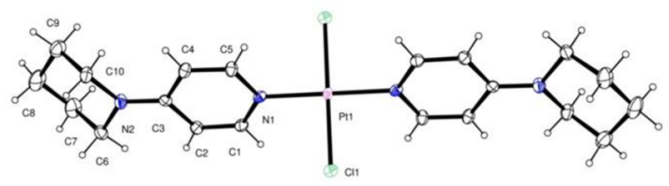

Figure 2. ORTEP plots of trans- $\left[\mathrm{Pt}\left(4-\mathrm{CF}_{3} \mathrm{py}\right)_{2} \mathrm{Cl}_{2}\right]$ (2), trans- $[\mathrm{Pt}(4-$ $\left.\mathrm{MeOpy})_{2} \mathrm{Cl}_{2}\right]$ (3), and trans-[Pt $\left(4-\left(\mathrm{CH}_{2}\right)_{5} \mathrm{Npy}_{2} \mathrm{Cl}_{2}\right]$ (5). Thermal ellipsoids are drawn with $50 \%$ probability. The asymmetric unit has only half of each molecule. For the figure, the other half of each structure was generated by using the inversion center. The trifluoromethyl group in $\mathbf{2}$ is disordered over three positions; only one position is shown for clarity.

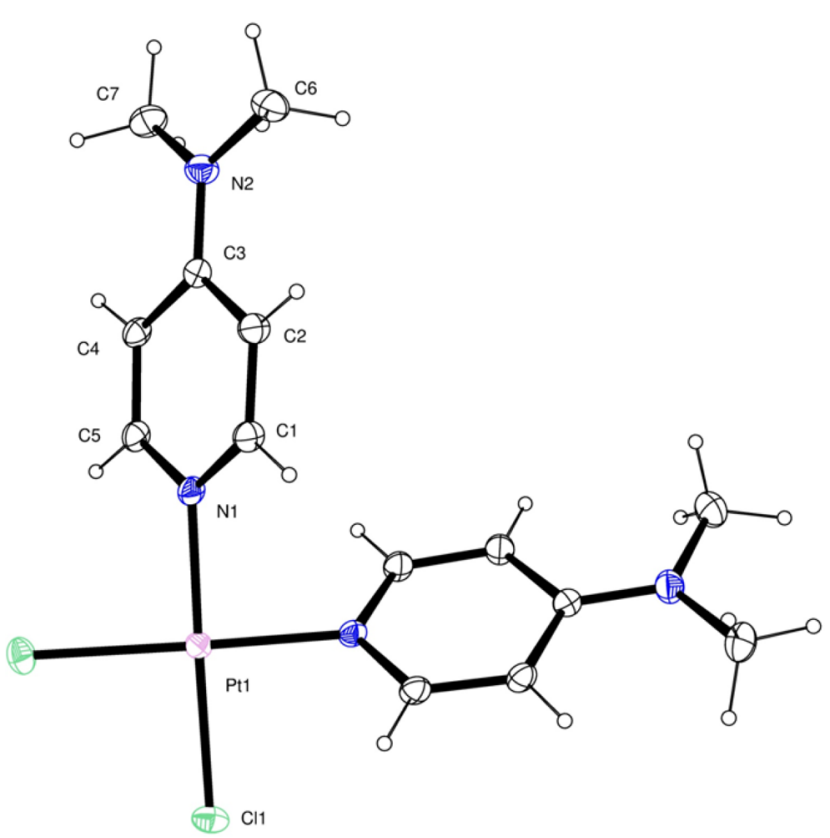

Figure 3. ORTEP plot of cis-[Pt(4- $\left.\left.\mathrm{Me}_{2} \mathrm{Npy}\right)_{2} \mathrm{Cl}_{2}\right]\left(4^{\prime}\right)$. Thermal ellipsoids are drawn with $50 \%$ probability. The asymmetric unit has only half of a molecule. For the figure, the other half of the structure was generated by a twofold rotational axis.

are shown in Figure 4. The asymmetric unit of $\mathbf{4 a}$ has two independent molecules (A and B), one of which lies on an inversion center. Two independent molecules are also found in the asymmetric unit of $\mathbf{5 a}$, both of them lying on an inversion center. The molecular structure of $7 \mathbf{a}$ has a twofold axis through the central $\mathrm{Pt}$ atom.

The $\mathrm{Pt}-\mathrm{N}$ and $\mathrm{C}-\mathrm{N}$ bond distances and the $\mathrm{C}-\mathrm{N}-\mathrm{C}, \mathrm{C}-$ $\mathrm{N}-\mathrm{Pt}$, and $\mathrm{N}-\mathrm{Pt}-\mathrm{N}$ bond angles (Table 6) all suggest very similar binding of the 4-Xpy ligands in the $\left[\mathrm{Pt}^{\mathrm{II}}(4-\mathrm{Xpy})_{4}\right]^{2+}$ cation of $3 \mathrm{a}, 4 \mathrm{a}, 5 \mathrm{a}$, and $7 \mathrm{a}$, with $\mathrm{N}-\mathrm{Pt}-\mathrm{N}$ bond angles close to $180^{\circ}$. In general, the $\mathrm{Pt}-\mathrm{N}$ bond distances for $\left[\mathrm{Pt}^{\mathrm{II}}(4-\mathrm{Xpy})_{4}\right]^{2+}$
$\left(\mathrm{X}=\mathrm{MeO}(3 \mathbf{a}), \mathrm{Me}_{2} \mathrm{~N}(4 \mathbf{a}),\left(\mathrm{CH}_{2}\right)_{5} \mathrm{~N}(5 \mathbf{a})\right.$, and $\left.\mathrm{Me}(7 \mathbf{a})\right)$ (Table 6) compare well with other $\mathrm{Pt}-\mathrm{N}\left(\mathrm{sp}^{2}\right)$ bond distances ranging from 1.99 to $2.08 \AA^{22,42,43}$ The canting angle for $\left[\mathrm{Pt}^{\mathrm{II}}(4-\mathrm{Xpy})_{4}\right]^{2+}$ cations varies from $\sim 89.2^{\circ}$ in $4 \mathrm{a}$ to $\sim 76.4^{\circ}$ in $5 a$, indicating less canting than in trans- $\left[\mathrm{Pt}^{\mathrm{II}}(4-\mathrm{Xpy})_{2} \mathrm{Cl}_{2}\right]$ compounds. The large differences in the canting angles indicate that there is a very low barrier preventing changes in the dihedral angle.

$\mathrm{Pt} \cdots \mathrm{Cl}$ and $\mathrm{CH} \cdots \mathrm{Cl}$ Nonbonded Distances in [Pt" (4$\mathrm{Xpy})_{4} \mathrm{Cl}_{2}\left(\mathrm{X}=\mathrm{MeO}(3 \mathrm{a}), \mathrm{Me}_{2} \mathrm{~N}(4 \mathrm{a}),\left(\mathrm{CH}_{2}\right)_{5} \mathrm{~N}(5 \mathrm{a})\right.$, or $\mathrm{Me}$ (7a)) Crystals. In almost all cases, the chloride counterions of the new crystals lie along pseudoaxial sites of the $\mathrm{Pt}$ (II) center but usually at distances that are a few tenths of an angstrom longer than the $\mathrm{Pt} \cdots \mathrm{Cl}$ contact distance of $\sim 3.5 \AA^{36,37}$ Including the two counterions and the cation, we can describe the configuration as resembling an axially elongated octahedron for both independent molecules in $\left[\mathrm{Pt}^{\mathrm{II}}\left(4-\left(\mathrm{CH}_{2}\right)_{5} \mathrm{Npy}\right)_{4}\right] \mathrm{Cl}_{2}$. $4 \mathrm{H}_{2} \mathrm{O}$ (5a) (in which $\mathrm{Pt}$ atoms occupy inversion centers with Pt... Cl distances of 3.885 and $3.912 \AA$ for the $\mathrm{A}$ and $\mathrm{B}$ molecules, respectively; see Supporting Information, Table S3) and Molecule $\mathrm{B}$ of $\left[\mathrm{Pt}^{\mathrm{II}}\left(4-\mathrm{Me}_{2} \mathrm{Npy}\right)_{4}\right] \mathrm{Cl}_{2}$ (4a) (with the $\mathrm{Pt}$ atom at an inversion center and the $\mathrm{Pt} \cdots \mathrm{Cl}$ distance $=3.793 \AA$ ). Molecule $\mathrm{A}$ of $\mathbf{4 a}$, the $\mathrm{Pt}$ atom has an elongated pseudo square pyramidal arrangement ( $\mathrm{Pt} \cdots \mathrm{Cl}$ distance is $3.675 \AA$ ), a structure serving as a model for $\left\{\left[\mathrm{Pt}^{\mathrm{II}}(4-\mathrm{Xpy})_{4}\right]^{2+}, \mathrm{Cl}^{-}\right\}^{+}$ion pairs with only one chloride present in solutions made with moderately polar solvents such as $\mathrm{CD}_{3} \mathrm{CN}$ (see below). The axially elongated octahedral arrangement in $\left[\mathrm{Pt}^{\mathrm{II}}(4-\mathrm{Mepy})_{4}\right] \mathrm{Cl}_{2} \cdot \mathrm{H}_{2} \mathrm{O}$ (7a) is less regular and lacks an inversion center; the two $\mathrm{Cl}^{-}$ anions nearest to $\mathrm{Pt}$ lie along the twofold rotational axis perpendicular to the $\mathrm{Pt}$ coordination plane, forming a pseudooctahedral arrangement with slightly differing $\mathrm{Pt} \cdots \mathrm{Cl}$ nonbonded distances of $3.470 \AA$ (Cl1) and $3.690 \AA(\mathrm{Cl} 2)$ (see Supporting Information, Table S3). In $\left[\mathrm{Pt}^{\mathrm{II}}(4-\mathrm{MeOpy})_{4}\right] \mathrm{Cl}_{2}$ (3a), there are disordered $\mathrm{Cl}^{-}$anions, precluding detailed geometric comparison of the arrangement of the $\mathrm{Cl}^{-}$anions relative to the cation; however, the elongated pseudooctahedral arrangement appears to be present in this case also. Finally, although this topic was neither noted nor discussed in the report of the structure of $\left[\mathrm{Pt}^{\mathrm{II}}(\mathrm{py})_{4}\right] \mathrm{Cl}_{2}(\mathbf{8 a})$, the structure does have axially located chlorides $(\mathrm{Pt} \cdots \mathrm{Cl}$ distance $3.631 \AA) .{ }^{44}$

In the structures of $4 \mathbf{a}, 5 \mathbf{a} \cdot 4 \mathrm{H}_{2} \mathrm{O}$, and $7 \mathbf{a} \cdot \mathrm{H}_{2} \mathrm{O}$, the distance between many of the pyridyl $\mathrm{H} 2 / 6$ protons and the $\mathrm{Cl}^{-}$ counteranions are short enough to be considered as a $\mathrm{CH}$... $\mathrm{Cl}$ intermolecular contact. ${ }^{45}$ The contacts for $\mathbf{4 a}$ are shown in Figure 5. Although invariably weak, such contacts are known to exhibit the characteristics of conventional hydrogen bonds, ${ }^{45-47}$ to occur widely in crystals, ${ }^{46,48}$ and possibly to extend beyond the $3.0 \AA$ van der Waals separation. ${ }^{48}$ The $\mathrm{CH} \cdots \mathrm{Cl}$ intermolecular contacts can be described as short $(<2.6 \AA$, $(d$ $\left.\ll \sum_{\mathrm{vdW}}\right)$, medium (2.6-3.0 $\AA,\left(d \leq \sum_{\mathrm{vdW}}\right)$, or long $(>3.0 \AA$, $\left(d>\sum_{\mathrm{vdW}}\right)^{46}$

The four nonbonding (py) $\mathrm{C}-\mathrm{H} \cdots \mathrm{Cl}$ distances found in each structure range from 2.711 to $2.884 \AA$ and from 2.802 to 2.980 $\AA$ for molecules $\mathrm{A}$ and $\mathrm{B}$, respectively, of $4 \mathrm{a}$, from 2.718 to $3.171 \AA$ and from 2.807 to $3.111 \AA$ for molecules $\mathrm{A}$ and $\mathrm{B}$, respectively, of $\mathbf{5 a} \cdot 4 \mathrm{H}_{2} \mathrm{O}$, and from 2.702 to $2.814 \AA$ for $7 \mathbf{a}$. $\mathrm{H}_{2} \mathrm{O}$ (see Supporting Information, Table S3). Most of these contacts are in the medium range. The nonbonding (py)C$\mathrm{H} \cdots \mathrm{Cl}$ distances observed for $7 \mathrm{a} \cdot \mathrm{H}_{2} \mathrm{O}$ (bearing the least basic 4Mepy ligand in the structures obtained here) have an average $=$ $2.761 \AA$, a value which is slightly shorter than the averages for 


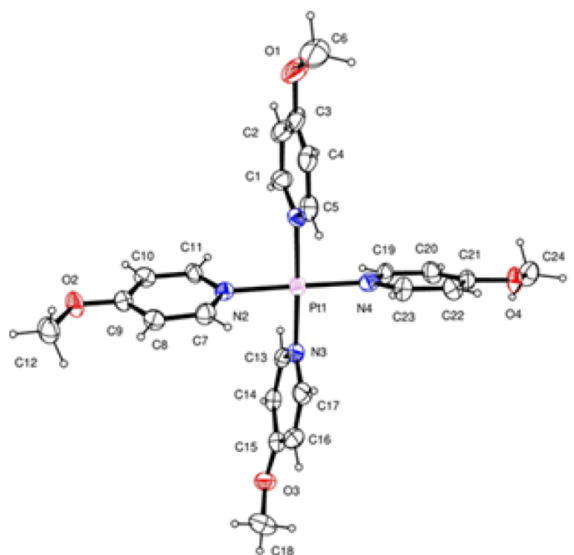

3a

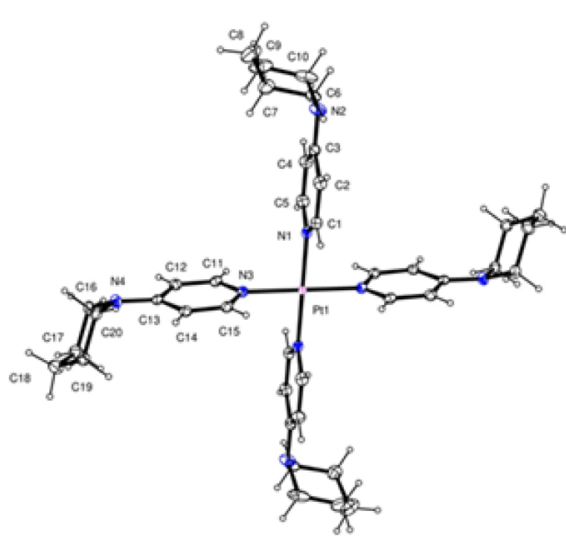

5a

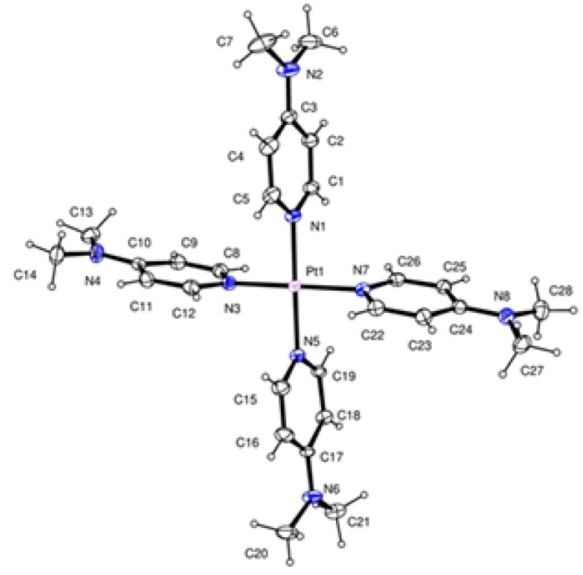

$4 \mathbf{a}$

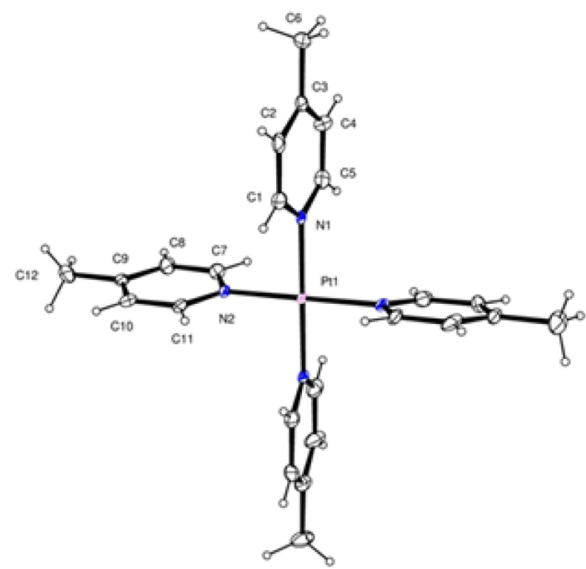

$7 \mathbf{a}$

Figure 4. ORTEP plots of the cations of $\left[\mathrm{Pt}(4-\mathrm{MeOpy})_{4}\right] \mathrm{Cl}_{2}(\mathbf{3 a}),\left[\mathrm{Pt}\left(4-\mathrm{Me}_{2} \mathrm{Npy}\right)_{4}\right] \mathrm{Cl}_{2}(\mathbf{4 a}),\left[\mathrm{Pt}\left(4-\left(\mathrm{CH}_{2}\right)_{5} \mathrm{Npy}\right)_{4}\right] \mathrm{Cl}_{2}(\mathbf{5 a})$, and $\left[\mathrm{Pt}(4-\mathrm{Mepy})_{4}\right] \mathrm{Cl}{ }_{2}$ (7a). Thermal ellipsoids are drawn with $50 \%$ probability.

Table 4. Selected Bond Distances $(\AA)$ and Angles (deg) for trans- $\left[\mathrm{Pt}(4-\mathrm{Xpy})_{2} \mathrm{Cl}_{2}\right]\left[\mathrm{X}=\mathrm{CF}_{3}(2), \mathrm{MeO}(3),\left(\mathrm{CH}_{2}\right)_{5} \mathrm{~N}(5), \mathrm{H}\right.$, and Me] Complexes

\begin{tabular}{|c|c|c|c|c|c|}
\hline & $\mathrm{CF}_{3}{ }^{a}$ & $\mathrm{MeO}^{a}$ & $\left(\mathrm{CH}_{2}\right)_{5} \mathrm{~N}^{a}$ & $\mathrm{H}^{b}$ & $\mathrm{Me}^{b}$ \\
\hline \multicolumn{6}{|c|}{ bond distances } \\
\hline Pt1-N1 & $2.0094(19)$ & $2.0283(13)$ & $2.026(2)$ & 1.977 & 2.024 \\
\hline Pt1-Cl1 & $2.3005(5)$ & $2.3000(4)$ & $2.2998(7)$ & 2.308 & 2.305 \\
\hline $\mathrm{C} 1-\mathrm{N} 1$ & $1.350(3)$ & $1.3473(19)$ & $1.335(3)$ & 1.370 & 1.333 \\
\hline $\mathrm{C} 5-\mathrm{N} 1$ & $1.350(3)$ & $1.351(2)$ & $1.350(3)$ & 1.408 & 1.348 \\
\hline \multicolumn{6}{|c|}{ bond angles } \\
\hline $\mathrm{N} 1-\mathrm{Pt} 1-\mathrm{Cl} 1$ & $90.24(5)$ & $90.34(4)$ & $90.52(7)$ & 91.99 & 89.80 \\
\hline N1-Pt1-Cl1 & $89.76(5)$ & $89.66(4)$ & $89.48(7)$ & 91.99 & 89.80 \\
\hline N1-Pt1-N1 & 180.0 & 180.0 & 180.0 & 180.00 & 180.00 \\
\hline Cl1-Pt1-Cl1 & 180.0 & 180.0 & 180.0 & 180.00 & 180.00 \\
\hline Pt1-N1-C1 & $121.12(16)$ & $121.71(10)$ & $121.03(17)$ & 123.89 & 120.00 \\
\hline Pt1-N1-C5 & $119.82(16)$ & $120.65(10)$ & $121.38(18)$ & 120.36 & 121.00 \\
\hline $\mathrm{C} 1-\mathrm{N} 1-\mathrm{C} 5$ & $119.0(2)$ & $117.63(13)$ & $117.6(2)$ & 115.50 & $118.3(5$ \\
\hline
\end{tabular}

${ }^{a} \mathrm{Pt}$ atom occupies an inversion center (half of the molecule is generated by an inversion center). ${ }^{b}$ Data for $\mathrm{X}=\mathrm{H}$ (refs 24 and 41 ) and Me (ref 24 ) are obtained from the literature, and no standard deviation was obtained from the database.

4a $(2.851 \AA)$ and for $5 \mathrm{a} \cdot 4 \mathrm{H}_{2} \mathrm{O}(2.954 \AA)$, the complexes with the highly basic 4- $\mathrm{Me}_{2} \mathrm{Npy}$ and $4-\left(\mathrm{CH}_{2}\right)_{5} \mathrm{Npy}$ ligands, respectively. This trend is expected and can be attributed to the higher $\delta+$ charge on the (py)C-H protons of 4-Mepy (7a.
$\mathrm{H}_{2} \mathrm{O}$ ), which leads to stronger $\mathrm{CH} \cdots \mathrm{Cl}$ intermolecular interactions and thus shorter (py) $\mathrm{C}-\mathrm{H} \cdots \mathrm{Cl}$ contacts. All of the $\left[\mathrm{Pt}^{\mathrm{II}}(4-\mathrm{Xpy})_{4}\right] \mathrm{Cl}_{2}$ crystals obtained in this study have relatively good 4-Xpy donors. For the analogues with weaker 
Table 5. Selected Bond Distances ( $⿱$ ) and Angles (deg) for cis- $\left[\mathrm{Pt}\left(4-\mathrm{Me}_{2} \mathrm{Npy}\right)_{2} \mathrm{Cl}_{2}\right]^{a}\left(4^{\prime}\right)$

\begin{tabular}{|c|c|}
\hline & bond distances \\
\hline Pt1-N1 & $2.0217(10)$ \\
\hline Pt1-Cl1 & $2.3028(3)$ \\
\hline $\mathrm{C} 1-\mathrm{N} 1$ & $1.3500(15)$ \\
\hline \multirow[t]{2}{*}{$\mathrm{C} 5-\mathrm{N} 1$} & $1.3569(14)$ \\
\hline & bond angles \\
\hline $\mathrm{N} 1^{i}-\mathrm{Pt} 1-\mathrm{N} 1$ & $88.47(6)$ \\
\hline $\mathrm{N} 1^{i}-\mathrm{Pt} 1-\mathrm{Cl}{ }^{i}$ & $178.40(3)$ \\
\hline $\mathrm{N} 1^{i}-\mathrm{Pt} 1-\mathrm{Cl} 1$ & $90.26(3)$ \\
\hline $\mathrm{Cl1}^{i}-\mathrm{Pt} 1-\mathrm{Cl} 1$ & $91.020(17)$ \\
\hline Pt1-N1-C1 & $122.57(7)$ \\
\hline Pt1-N1-C5 & $120.41(8)$ \\
\hline $\mathrm{C} 1-\mathrm{N} 1-\mathrm{C} 5$ & $116.81(10)$ \\
\hline
\end{tabular}

${ }^{a}$ Symmetry operator $(i)=-x+1, y,-z+3 / 2$.

donor 4-Xpy ligands $\left(\mathrm{X}=\mathrm{CN}, \mathrm{CF}_{3}\right.$, and $\left.\mathrm{MeCO}\right)$, the chloride displaces the 4-Xpy ligand, as discussed below, precluding the isolation of crystals. However, we expect that the (py) $\mathrm{C}-\mathrm{H} \cdots \mathrm{Cl}$ contacts for complexes possessing less basic 4-Xpy donors would be shorter than those observed here for $4 a, 5 a \cdot 4 \mathrm{H}_{2} \mathrm{O}$, and $7 \mathbf{a} \cdot \mathrm{H}_{2} \mathrm{O}$.

NMR Spectroscopy. Selected ${ }^{1} \mathrm{H}$ NMR spectroscopic data for 4-Xpy ligands and complexes, including the H2/6 (more

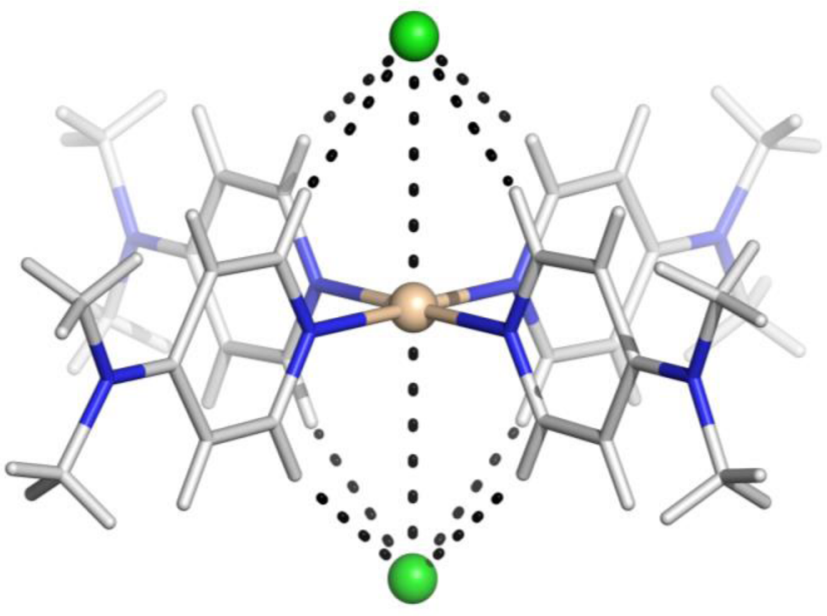

Figure 5. Pseudo-elongated octahedral geometry in $\left[\mathrm{Pt}\left(4-\mathrm{Me}_{2} \mathrm{Npy}\right)_{4}\right]$ $\mathrm{Cl}_{2}$ (4a) formed by nonbonding (py) $\mathrm{C}-\mathrm{H} \cdots \mathrm{Cl}$ interactions between the aromatic protons closest to the platinum atom and the two nearest $\mathrm{Cl}^{-}$anions.

downfield) and $\mathrm{H} 3 / 5$ aromatic ${ }^{1} \mathrm{H}$ NMR signals assigned in accordance with the widely observed pattern, ${ }^{1,49}$ are collected in Tables 1-3 and in the Supporting Information. The atom-

Table 6. Selected Bond Distances $(\AA)$ and Angles (deg) for $\left[\mathrm{Pt}(4-\mathrm{Xpy})_{4}\right] \mathrm{Cl}_{2}\left[\mathrm{X}=\mathrm{MeO}(3 \mathrm{a}), \mathrm{Me}_{2} \mathrm{~N}(4 \mathrm{a}),\left(\mathrm{CH}_{2}\right)_{5} \mathrm{~N}(5 \mathrm{a})\right.$, and $\mathrm{Me}$ (7a)] Complexes ${ }^{a}$

\begin{tabular}{|c|c|c|c|c|c|c|}
\hline & $3 a$ & $4 a(A)$ & $4 a(B)$ & $5 a(A)$ & $5 a(B)$ & $7 a$ \\
\hline \multicolumn{7}{|c|}{ bond distances } \\
\hline Pt1-N1 & $2.014(8)$ & $2.020(4)$ & $2.008(5)$ & $2.014(2)$ & $2.010(2)$ & $2.016(5)$ \\
\hline Pt1-N2 & $2.027(9)$ & $2.011(5)$ & & & & $2.033(6)$ \\
\hline $\operatorname{Pt} 1-\mathrm{N}(m)^{a}$ & $2.026(9)^{b}$ & $2.016(4)^{b}$ & $2.026(4)^{b}$ & $2.021(2)^{b}$ & $2.005(2)^{b}$ & \\
\hline $\operatorname{Pt} 1-\mathrm{N}(n)^{a}$ & $2.008(9)^{c}$ & $2.013(5)^{c}$ & & & & \\
\hline \multicolumn{7}{|c|}{ bond angles } \\
\hline $\mathrm{N} 1-\mathrm{Pt} 1-\mathrm{N}(m)$ & $177.9(3)^{b}$ & $179.32(17)^{b}$ & $180.0(0)^{d}$ & $180.0(0)^{d}$ & $180.0(0)^{d}$ & $179.6(3)^{d}$ \\
\hline $\mathrm{N} 2-\mathrm{Pt} 1-\mathrm{N}(n)$ & $179.0(4)^{c}$ & $178.95(18)^{c}$ & & & & $179.3(3)^{e}$ \\
\hline $\mathrm{N} 1-\mathrm{Pt} 1-\mathrm{N} 2$ & $89.8(3)$ & $88.12(18)$ & & & & $90.3(2)$ \\
\hline $\mathrm{N} 1-\mathrm{Pt} 1-\mathrm{N}(m)$ & & & $92.11(19)^{b}, 87.89(19)^{b}$ & $92.51(9)^{b}, 87.49(9)^{b}$ & $91.56(9)^{b}, 88.44(9)^{b}$ & \\
\hline $\mathrm{N} 1-\mathrm{Pt} 1-\mathrm{N}(n)$ & $91.1(4)^{c}$ & $92.23(18)^{e}$ & & & & $89.7(2)^{e}$ \\
\hline $\mathrm{N} 2-\mathrm{Pt} 1-\mathrm{N}(m)$ & $88.3(3)^{b}$ & $92.42(18)^{b}$ & & & & \\
\hline $\mathrm{N}(m)-\mathrm{Pt} 1-\mathrm{N}(m)$ & & & $180.0(0)^{b}$ & $180.0(0)^{b}$ & & \\
\hline $\mathrm{N} 1-\mathrm{Pt} 1-\mathrm{N}(m)$ & & & & & $180.0(0)^{b}$ & \\
\hline $\mathrm{N}(m)-\mathrm{Pt} 1-\mathrm{N}(n)$ & $90.8(4)^{b, c}$ & $87.22(18)^{b, c}$ & & & & \\
\hline $\mathrm{C} 1-\mathrm{N} 1-\mathrm{C} 5$ & $118.7(10)$ & $117.3(5)$ & $117.5(5)$ & $117.3(3)$ & $117.4(2)$ & $118.6(6)$ \\
\hline $\mathrm{C} 1-\mathrm{N} 1-\mathrm{Pt} 1$ & $120.4(7)$ & $122.0(4)$ & $122.2(4)$ & $120.33(19)$ & $121.17(19)$ & $120.7(5)$ \\
\hline $\mathrm{C} 5-\mathrm{N} 1-\mathrm{Pt} 1$ & $120.8(8)$ & $120.7(4)$ & $120.2(4)$ & $122.3(2)$ & $121.5(2)$ & $120.8(5)$ \\
\hline $\mathrm{C} 7-\mathrm{N} 2-\mathrm{C} 11$ & $118.5(10)$ & & & & & $119.1(6)$ \\
\hline \multicolumn{7}{|l|}{$\mathrm{C} 11-\mathrm{N} 2-\mathrm{C} 15$} \\
\hline $\mathrm{C} 11-\mathrm{N}(m)-\mathrm{C} 15$ & & & & $117.4(2)^{b}$ & $116.9(2)^{b}$ & \\
\hline $\mathrm{C} 7-\mathrm{N} 2-\mathrm{Pt} 1$ & $120.6(7)$ & & & & & $120.1(5)$ \\
\hline $\mathrm{C} 8-\mathrm{N} 2-\mathrm{C} 12$ & & $116.7(5)$ & & & & \\
\hline $\mathrm{C} 8-\mathrm{N} 2-\mathrm{Pt} 1$ & & $120.0(4)$ & & & & \\
\hline $\mathrm{C} 8-\mathrm{N}(m)-\mathrm{Pt} 1$ & & & $121.5(4)^{b}$ & & & \\
\hline $\mathrm{C} 11-\mathrm{N} 2-\mathrm{Pt} 1$ & $120.9(7)$ & & & & & $120.8(5)$ \\
\hline $\mathrm{C} 11-\mathrm{N}(m)-\mathrm{Pt} 1$ & & & & $121.66(19)^{b}$ & $121.0(2)^{b}$ & \\
\hline $\mathrm{C} 12-\mathrm{N} 2-\mathrm{Pt} 1$ & & $122.8(4)$ & & & & \\
\hline $\mathrm{C} 12-\mathrm{N}(m)-\mathrm{Pt} 1$ & & & $120.6(4)$ & & & \\
\hline $\mathrm{C} 15-\mathrm{N} 2-\mathrm{Pt} 1$ & & & & & & \\
\hline $\mathrm{C} 15-\mathrm{N}(m)-\mathrm{Pt} 1$ & & & & $120.78(19)$ & $122.05(19)^{b}$ & \\
\hline
\end{tabular}

${ }^{a} m$ and $n$ vary according to the R group. ${ }^{b} m=3 .{ }^{c} n=4 .{ }^{d} m=1 .{ }^{e} n=2$. 
numbering system used in this NMR discussion is shown in Scheme 1.

Previous limited NMR studies on cis/trans- $\left[\mathrm{Pt}^{\mathrm{II}}(\mathrm{py})_{2} \mathrm{Cl}_{2}\right]$ and cis/trans- $\left[\mathrm{Pt}^{\mathrm{II}}(4-\mathrm{Xpy})_{2} \mathrm{Cl}_{2}\right]$ complexes employed pyridine-type ligands having properties in a narrow range. ${ }^{23-25,27,33}$ In $\mathrm{CDCl}_{3}$, the $\mathrm{H} 2 / 6$ signal of py in trans- $\left[\mathrm{Pt}^{\mathrm{II}}(\mathrm{py})_{2} \mathrm{Cl}_{2}\right]$ was shifted downfield by $\sim 0.3 \mathrm{ppm}$ as compared to free ligand ${ }^{24}$ (see footnotes in Table 1 and Supporting Information, Table S5); this characteristic downfield chemical shift change giving a positive value for the parameter $\Delta \delta\left(\Delta \delta=\delta_{\text {complex }}-\delta_{\text {ligand }}\right)$ is approximately the expected value ${ }^{24}$ and is usually interpreted as resulting from the decrease in the electron density of the ligand upon coordination. ${ }^{17,24,27}$

In the present study, we first examined relatively basic ligands that can be used in our bioconjugation approach and found that the trans- $\left[\mathrm{Pt}^{\mathrm{II}}(4-\mathrm{Xpy})_{2} \mathrm{Cl}_{2}\right]$ products had rather small $\mathrm{H} 2 / 6 \Delta \delta$ values in $\mathrm{CDCl}_{3}(\sim 0.1 \mathrm{ppm})$. This $\mathrm{H} 2 / 6 \Delta \delta$ value is comparable to that reported for the $\left[\mathrm{Pt}^{\mathrm{II}}(\mathrm{py})_{2} \mathrm{Cl}_{2}\right]$ cis isomer $(\sim 0.1 \mathrm{ppm})$ as compared to the trans isomer $(\sim 0.3 \mathrm{ppm}){ }^{23,24}$ The smaller $\mathrm{H} 2 / 6 \Delta \delta$ value for $c i s-\left[\mathrm{Pt}^{\mathrm{II}}(\mathrm{py})_{2} \mathrm{Cl}_{2}\right]$ versus trans$\left[\mathrm{Pt}^{\mathrm{II}}(\mathrm{py})_{2} \mathrm{Cl}_{2}\right]$ was attributed to the mutual anisotropic shielding effect exerted by adjacent cis anisotropic py ligands. ${ }^{23,27}$ Thus, the NMR data do not provide a very useful guide in synthetic studies of trans- $\left[\mathrm{Pt}^{\mathrm{II}}(4-\mathrm{Xpy})_{2} \mathrm{Cl}_{2}\right]$ complexes. In addition, we also observed side products having very downfield $\mathrm{H} 2 / 6$ signals. Thus, to understand the factors that influence $\mathrm{H} 2 / 6 \Delta \delta$ values, we prepared and examined complexes of 4 -Xpy ligands having a wide range of donor ability.

trans-[Pt" $\left.(4-\mathrm{Xpy})_{2} \mathrm{Cl}_{2}\right]$ Complexes. As expected, coordination of 4-Xpy to form trans- $\left[\mathrm{Pt}^{\mathrm{II}}(4-\mathrm{Xpy})_{2} \mathrm{Cl}_{2}\right]$ complexes led to positive $\Delta \delta$ values for the $\mathrm{H} 2 / 6$ signal (Table 1 ). For both the free 4-Xpy ligands and the trans- $\left[\mathrm{Pt}^{\mathrm{II}}(4-\mathrm{Xpy})_{2} \mathrm{Cl}_{2}\right]$ complexes, the $\mathrm{H} 2 / 6$ and $\mathrm{H} 3 / 5$ signals (in $\mathrm{CDCl}_{3}$ ) appeared farther upfield with increasing basicity of the 4-Xpy ligand (Table 1). This trend can be attributed to the greater electron richness of the more basic 4-Xpy ligands. Plots of the chemical shift of the H2/6 signals of 4-Xpy and of trans-[ $\mathrm{Pt}^{\mathrm{II}}(4-$ $\mathrm{Xpy})_{2} \mathrm{Cl}_{2}$ ] complexes versus the $\mathrm{p} K_{\mathrm{a}}$ of 4 -Xpy are linear and have a negative slope (Figure 6). For plots of both series of complexes in Figure 6, the order is as follows: 4-CNpy $(\mathbf{1})>4$ -

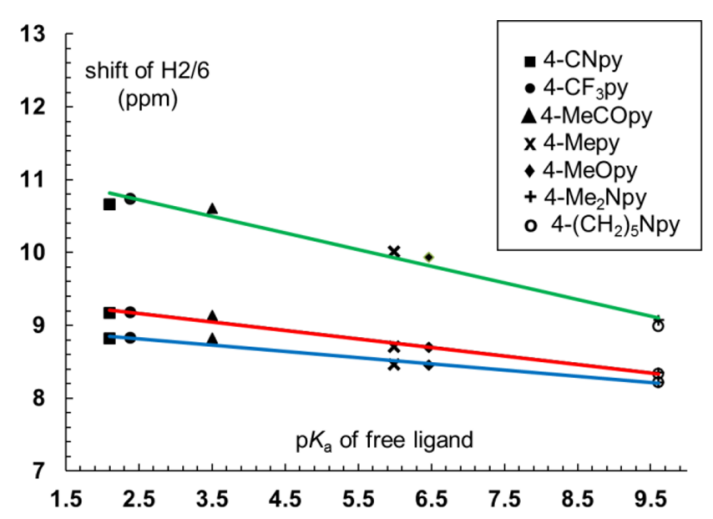

Figure 6. Shifts (ppm) of the $\mathrm{H} 2 / 6 \mathrm{NMR}$ signals (in $\mathrm{CDCl}_{3}, 25^{\circ} \mathrm{C}$ ) of 4-Xpy both free ( $5 \mathrm{mM}$, blue line; slope $\left.=-0.0856, R^{2}=0.972\right)$ and coordinated in trans- $\left[\mathrm{Pt}(4-\mathrm{Xpy})_{2} \mathrm{Cl}_{2}\right](5 \mathrm{mM}$, red line; slope = $\left.-0.1165, R^{2}=0.9862\right)$ and $\left[\mathrm{Pt}(4-\mathrm{Xpy})_{4}\right] \mathrm{Cl}_{2}(5 \mathrm{mM}$, green line; slope $\left.=-0.2291, R^{2}=0.9789\right)$ plotted vs the $\mathrm{p} K_{\mathrm{a}}$ of the free 4-Xpy. Data for " $\left[\mathrm{Pt}(4-\mathrm{Xpy})_{4}\right] \mathrm{Cl}_{2}$ " for $\mathrm{X}=\mathrm{CN}, \mathrm{CF}_{3}$, and $\mathrm{MeCO}$ were obtained from the nitrate salt as explained in the text.
$\mathrm{CF}_{3}$ py (2) > 4-MeCOpy (6) > 4-Mepy (7) > 4-MeOpy (3) > $\left.4-\mathrm{Me}_{2} \mathrm{Npy}\right)(4) \approx 4-\left(\mathrm{CH}_{2}\right)_{5} \mathrm{Npy}(5)$. The slightly steeper negative slope for the complexes than for the free ligand (Figure 6) can be attributed to the size of the synergistic decrease of the inductive effect of the $\mathrm{Pt}(\mathrm{II})$ metal center caused by the two mutually trans pyridyl rings. This decrease of the $\mathrm{Pt}(\mathrm{II})$ inductive effect is much smaller when the 4-Xpy ligand is a poor donor. Thus, $\mathrm{H} 2 / 6 \Delta \delta$ is larger. The $\mathrm{H} 2 / 6 \Delta \delta$ values decrease linearly with increasing $\mathrm{p} K_{\mathrm{a}}$ of 4 -Xpy from 0.35 to $0.11 \mathrm{ppm}$ (Table 1 and Figure 7 ) in the same order as the plots in Figure 6.

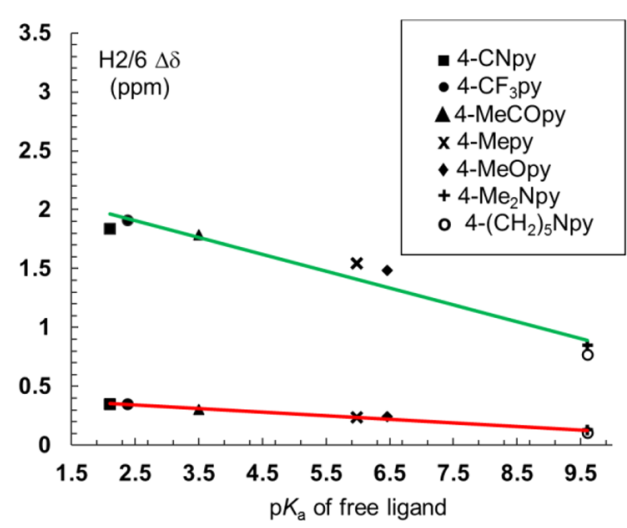

Figure 7. Change in shift $(\Delta \delta$, ppm $)$ of the $\mathrm{H} 2 / 6{ }^{1} \mathrm{H}$ NMR signal in $\mathrm{CDCl}_{3}$ upon coordination of 4-Xpy to form trans- $\left[\mathrm{Pt}(4-\mathrm{Xpy})_{2} \mathrm{Cl}_{2}\right]$ (red line; slope $\left.=-0.0305, R^{2}=0.9858\right)$ and $\left[\mathrm{Pt}(4-\mathrm{Xpy})_{4}\right] \mathrm{Cl}_{2}$ (green line; slope $\left.=-0.1435, R^{2}=0.9449\right)$ plotted vs the $\mathrm{p} K_{\mathrm{a}}$ of free 4-Xpy. Data for " $\left[\mathrm{Pt}(4-\mathrm{Xpy})_{4}\right] \mathrm{Cl}_{2}$ " for $\mathrm{X}=\mathrm{CN}, \mathrm{CF}_{3}$, and $\mathrm{MeCO}$ were obtained from the nitrate salt as explained in the text.

Dependence of NMR Spectra (in $\mathrm{CDCl}_{3}$ ) of [Pt"(4$\left.X p y)_{4}\right] \mathrm{Cl}_{2}$ Complexes on the Nature of $\mathrm{X}$. As mentioned, side products having very downfield $\mathrm{H} 2 / 6$ signals found in early phases of this study were later identified as the $\left[\mathrm{Pt}^{\mathrm{II}}(4-\right.$ $\left.\mathrm{Xpy})_{4}\right] \mathrm{Cl}_{2}$ salts. To obtain related products $\left(\left[\mathrm{Pt}^{\mathrm{II}}(4-\mathrm{Xpy})_{4}\right] \mathrm{Y}_{2}\right)$ with poor donor 4-Xpy ligands, we used other poorly coordinating or non-coordinating counterions. Within any series of $\left[\mathrm{Pt}^{\mathrm{II}}(4-\mathrm{Xpy})_{4}\right] \mathrm{Y}_{2}$ complexes regardless of the identity of the $\mathrm{Y}$ counterion, the $\mathrm{H} 2 / 6$ and $\mathrm{H} 3 / 5$ signals appeared farther upfield with increasing basicity of the 4-Xpy ligands, as we found for the trans- $\left[\mathrm{Pt}^{\mathrm{II}}(4-\mathrm{Xpy})_{2} \mathrm{Cl}_{2}\right]$ complexes.

We begin the discussion with the $\left[\mathrm{Pt}^{\mathrm{II}}(4-\mathrm{Xpy})_{4}\right] \mathrm{Cl}_{2}$ complexes in $\mathrm{CDCl}_{3}$ (Table 2), because we have the most extensive solution and structural data for the $\mathrm{Y}=\mathrm{Cl}^{-}$complexes and because $\Delta \delta$ is greater by $\sim 1 \mathrm{ppm}$ when $\mathrm{Y}=\mathrm{Cl}^{-}$than when $\mathrm{Y}=$ other counterions; we conclude with a discussion of other solvents and $\left[\mathrm{Pt}^{\mathrm{II}}(4-\mathrm{Xpy})_{4}\right] \mathrm{Y}_{2}$ complexes with other $\mathrm{Y}$ counterions. In plots of the $\mathrm{H} 2 / 6$ shifts of $\left[\mathrm{Pt}^{\mathrm{II}}(4-\mathrm{Xpy})_{4}\right] \mathrm{Cl}_{2}$ and trans$\left[\mathrm{Pt}^{\mathrm{II}}(4-\mathrm{Xpy})_{2} \mathrm{Cl}_{2}\right]$ in $\mathrm{CDCl}_{3}$ versus the $\mathrm{pK}$ of 4 -Xpy (Figure 6), the negative slope for the $\left[\mathrm{PII}^{\mathrm{II}}(4-\mathrm{Xpy})_{4}\right] \mathrm{Cl}_{2}$ series is much steeper than for the trans-[ $\left.\mathrm{Pt}^{\mathrm{II}}(4-\mathrm{Xpy})_{2} \mathrm{Cl}_{2}\right]$ series. This observation can be interpreted as discussed above by noting that now there are four 4-Xpy ligands synergistically influencing the inductive effect of the $\mathrm{Pt}^{\mathrm{II}}$ metal center and that the $\mathrm{H} 2 / 6$ shift is sensitive to this inductive effect. As a further illustration of the synergism, the $\Delta \delta$ values in $\mathrm{CDCl}_{3}$ for $\left[\mathrm{Pt}^{\mathrm{II}}(4-\mathrm{Xpy})_{4}\right] \mathrm{Cl}_{2}$ (1.91-0.77 ppm, Table 2) decrease linearly with increasing $\mathrm{p} K_{\mathrm{a}}$ of 4-Xpy (Figure 7) to a much greater extent than the trans$\left[\mathrm{Pt}^{\mathrm{II}}(4-\mathrm{Xpy})_{2} \mathrm{Cl}_{2}\right]$ series. 
The ${ }^{1} \mathrm{H}$ NMR shift data, especially for $\mathrm{H} 2 / 6$ at $8.84 \mathrm{ppm}$, reported by Pazderski et al. ${ }^{23}\left[\mathrm{Pt}^{\mathrm{II}}(\mathrm{py})_{4}\right] \mathrm{Cl}_{2}$ in $\mathrm{CDCl}_{3}$ do not agree at all with the $\mathrm{H} 2 / 6$ shifts $(\sim 10 \mathrm{ppm})$ observed here for the $\left[\mathrm{Pt}^{\mathrm{II}}(4-\mathrm{Xpy})_{4}\right] \mathrm{Cl}_{2}$ complexes with moderate donor 4-Xpy ligands (Table 2 and Supporting Information, Table S5). To independently verify the reported preparation ${ }^{23}$ and characterization $^{44}$ of $\left[\mathrm{Pt}^{\mathrm{II}}(\mathrm{py})_{4}\right] \mathrm{Cl}_{2}(\mathbf{8 a})$, we prepared $\left[\mathrm{Pt}^{\mathrm{II}}(\mathrm{py})_{4}\right] \mathrm{Cl}_{2}$ by our method and obtained colorless crystals with unit-cell parameters identical to those reported for $\left[\mathrm{Pt}(\mathrm{py})_{4}\right] \mathrm{Cl}_{2} \cdot{ }^{44}$ The $\mathrm{H} 2 / 6$ shift $(10.36 \mathrm{ppm})$ in $\mathrm{CDCl}_{3}$ at $25{ }^{\circ} \mathrm{C}$ for our $\left[\mathrm{Pt}(\mathrm{py})_{4}\right] \mathrm{Cl}_{2}$ crystals (see Supporting Information, Table S5) is entirely consistent with the shift value expected from our data. Concluding that some error was made in the previous work, ${ }^{23}$ we turned our attention to elucidating the factors contributing to the very downfield position of these $\mathrm{H} 2 / 6$ signals.

Cause of the Unusually Large Downfield H2/6 Signals of $\left[\mathrm{Pt}^{\prime \prime}(4-\mathrm{Xpy})_{4}\right] \mathrm{Cl}_{2}$ Complexes. Understanding the specific factors causing the larger $\Delta \delta \mathrm{H} 2 / 6$ values for $\left[\mathrm{Pt}^{\mathrm{II}}(4-\mathrm{Xpy})_{4}\right] \mathrm{Cl}_{2}$ salts than for salts with other counterions (Table 2) is an important goal of our study. Another interesting feature observed for the $\left[\mathrm{Pt}^{\mathrm{II}}(4-\mathrm{Xpy})_{4}\right] \mathrm{Cl}_{2}$ salts is their high solubility in $\mathrm{CDCl}_{3}$, a solvent of low polarity. We believe that the $\mathrm{Pt}^{\mathrm{II}}(4-$ $\left.\mathrm{Xpy})_{4}\right] \mathrm{Cl}_{2}$ solubility in $\mathrm{CDCl}_{3}$ provides clear evidence that electrostatic attraction leads to the existence of $\left\{\left[\mathrm{Pt}^{\mathrm{II}}(4-\right.\right.$ $\left.\left.\mathrm{Xpy})_{4}\right]^{2+}, 2 \mathrm{Cl}^{-}\right\}$ion pairs having overall low charge and containing multiple stabilizing (py) $\mathrm{CH} \cdots \mathrm{Cl}$ hydrogen bonds similar to those found in the solid state (Figure 5 and Supporting Information, Table S3).

We believe that there can be no doubt that ion pairs between the $\left[\mathrm{Pt}^{\mathrm{II}}(4-\mathrm{Xpy})_{4}\right]^{2+}$ dication and the various $\mathrm{Y}$ anions do exist in the low-dielectric solvent $\mathrm{CDCl}_{3}$. We hypothesize that in $\mathrm{CDCl}_{3}$ solutions of $\left[\mathrm{Pt}^{\mathrm{II}}(4-\mathrm{Xpy})_{4}\right] \mathrm{Cl}_{2}$ complexes the close proximity of the $\mathrm{Cl}^{-}$counterion to the $\mathrm{H} 2 / 6$ protons of the coordinated 4-Xpy pyridyl ring within such ion pairs results in the formation of multiple $\mathrm{CH} \cdots \mathrm{Cl}$ contacts between $\mathrm{H} 2 / 6$ and $\mathrm{Cl}^{-}$and in dynamic ion pairs similar to the elongated pseudooctahedrons found in the solid (Figure 5). The formation of hydrogen bonds is known to lead to downfield shift changes in the ${ }^{1} \mathrm{H}$ NMR signals. ${ }^{50,51}$ Thus, the very downfield $\mathrm{H} 2 / 6$ signals for $\left[\mathrm{Pt}^{\mathrm{II}}(4-\mathrm{Xpy})_{4}\right] \mathrm{Cl}_{2}$ complexes in $\mathrm{CDCl}_{3}$ are consistent with the presence of $\mathrm{CH} \cdots \mathrm{Cl}$ hydrogen bonds, proving beyond any doubt that specific cation-anion contacts exist within such dynamic ion pairs in solution is probably not possible, but we believe that the results of several solution studies to be described next lead to a very compelling case for the existence of fully formed $\left\{\left[\mathrm{Pt}^{\mathrm{II}}(4-\mathrm{Xpy})_{4}\right]^{2+}, 2 \mathrm{Cl}^{-}\right\}$ion pairs containing multiple $\mathrm{CH} \cdots \mathrm{Cl}$ interactions in $\mathrm{CDCl}_{3}$.

To assess our hypothesis, we first examined the effect of $\left[\mathrm{Et}_{4} \mathrm{~N}\right] \mathrm{Cl}$ addition on the $\mathrm{H} 2 / 6$ signals of $\left[\mathrm{Pt}^{\mathrm{II}}(4-\mathrm{Xpy})_{4}\right] \mathrm{Cl}_{2}$ in $\mathrm{CDCl}_{3}$ for $\mathrm{X}=\mathrm{MeO}(\mathbf{3 a}), \mathrm{Me}_{2} \mathrm{~N}(4 \mathbf{a}),\left(\mathrm{CH}_{2}\right)_{5} \mathrm{~N}(\mathbf{5 a})$, and $\mathrm{Me}$ (7a). If the $\left\{\left[\mathrm{Pt}^{\mathrm{II}}(4-\mathrm{Xpy})_{4}\right]^{2+}, 2 \mathrm{Cl}^{-}\right\}$ion pairs were not fully formed, the $\mathrm{H} 2 / 6$ signal would shift downfield because the added chloride would drive the equilibrium toward the formation of more $\left\{\left[\mathrm{Pt}^{\mathrm{II}}(4-\mathrm{Xpy})_{4}\right]^{2+}, 2 \mathrm{Cl}^{-}\right\}$ion pairs. Downfield shifts are also expected if the ion pairs have only one chloride ion, $\left\{\left[\mathrm{Pt}^{\mathrm{II}}(4-\mathrm{Xpy})_{4}\right]^{2+}, \mathrm{Cl}^{-}\right\}^{+}$. As the $\mathrm{Cl}^{-}$concentration was increased, the $\mathrm{H} 2 / 6$ signals shifted slightly upfield by $\sim 0.02$ ppm for $3 a$ and $7 \mathrm{a}$, by $0.17 \mathrm{ppm}$ for $4 \mathrm{a}$, and by $0.18 \mathrm{ppm}$ for $5 \mathrm{a}$ as up to $25 \mathrm{mM}\left[\mathrm{Et}_{4} \mathrm{~N}\right] \mathrm{Cl}$ was added (see Supporting Information, Figure S5). The absence of downfield shifts supports the proposal that $\left\{\left[\mathrm{Pt}^{\mathrm{II}}(4-\mathrm{Xpy})_{4}\right]^{2+}, 2 \mathrm{Cl}^{-}\right\}$ion pairs are already fully formed in the absence of added chloride salt. The minor upfield shifting is most consistent with salt effects.

A similar $\left[\mathrm{Et}_{4} \mathrm{~N}\right] \mathrm{Cl}$ salt effect study could not be conducted for $\left[\mathrm{Pt}^{\mathrm{II}}(4-\mathrm{Xpy})_{4}\right] \mathrm{Cl}_{2}$ complexes with the very weak donor 4Xpy ligands $\left(\mathrm{X}=\mathrm{CN}, \mathrm{CF}_{3}\right.$, and $\left.\mathrm{MeCO}\right)$ because the chloride salts could not be isolated. However, solutions containing $\left\{\left[\mathrm{Pt}^{\mathrm{II}}(4-\mathrm{Xpy})_{4}\right]^{2+}, 2 \mathrm{Cl}^{-}\right\}$ion pairs in $\mathrm{CDCl}_{3}$ at $25^{\circ} \mathrm{C}$ could be generated easily by adding $\left[\mathrm{Et}_{4} \mathrm{~N}\right] \mathrm{Cl}$ to suspensions of $\left[\mathrm{Pt}^{\mathrm{II}}(4-\right.$ $\left.\mathrm{Xpy})_{4}\right]\left(\mathrm{NO}_{3}\right)_{2}\left[\mathrm{X}=\mathrm{CN}(\mathbf{l e}), \mathrm{CF}_{3}(\mathbf{2 e})\right.$, and $\left.\mathrm{MeCO}(\mathbf{6 e})\right]$ salts, which are insoluble or poorly soluble in $\mathrm{CDCl}_{3}$; shift data from NMR spectra recorded within $\sim 5$ to $30 \mathrm{~min}$ after addition of $\left[\mathrm{Et}_{4} \mathrm{~N}\right] \mathrm{Cl}$ can be found in Table 2 and Figures 6 and 7. The $\Delta \delta$ values found for $\left\{\left[\mathrm{Pt}^{\mathrm{II}}(4-\mathrm{Xpy})_{4}\right]^{2+}, 2 \mathrm{Cl}^{-}\right\}$ion pairs (Table 2) are $\sim 1.8$ to $1.9 \mathrm{ppm}$ when $4-\mathrm{Xpy}$ is one of these poor ligands, as compared to $\Delta \delta \approx 1.5 \mathrm{ppm}$ for a medium donor ligand (e.g., $\mathrm{X}$ $=\mathrm{Me})$ and $\Delta \delta<0.9 \mathrm{ppm}$ for the stronger donor ligand $(\mathrm{X}=4$ $\left.\mathrm{Me}_{2} \mathrm{~N}\right)$. These $\Delta \delta$ values are fully consistent with a decrease in the partial positive charge $\delta^{+}$of the $\mathrm{H} 2 / 6$ protons with increasing 4-Xpy pyridyl ring electron richness. A decrease in $\delta^{+}$ of the $\mathrm{H} 2 / 6$ protons in turn diminishes the strength of the specific $\mathrm{H} 2 / 6 \mathrm{H}$-bonding interactions with the chloride ion within the ion pair.

As an aside, as expected, NMR scans of these suspensions gave no or very weak signals (cf. Figure 8 for $\mathrm{X}=\mathrm{CN}(\mathbf{1 e})$ ).

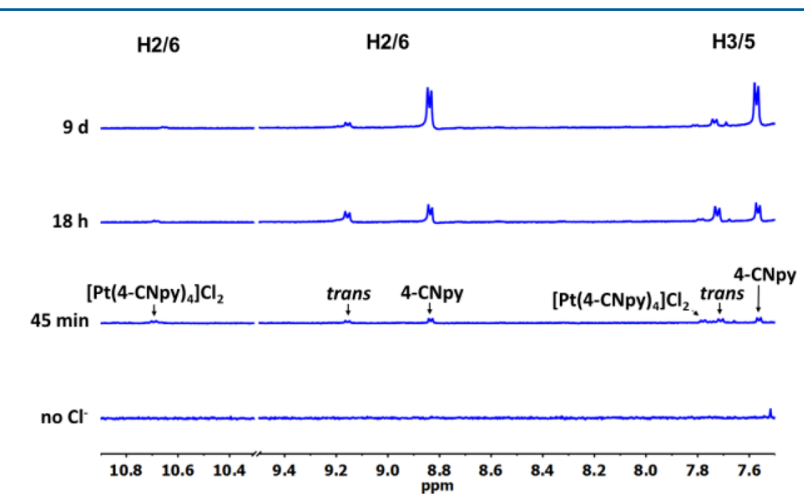

Figure 8. Stacked plot of the aromatic region of ${ }^{1} \mathrm{H}$ NMR spectra (in $\left.\mathrm{CDCl}_{3}, 25{ }^{\circ} \mathrm{C}\right)$ for the treatment of $\left[\mathrm{Pt}(4-\mathrm{CNpy})_{4}\right]\left(\mathrm{NO}_{3}\right)_{2}(\mathbf{1 e}, 5$ $\mathrm{mM})$ with $\left[\mathrm{Et}_{4} \mathrm{~N}\right] \mathrm{Cl}(125 \mathrm{mM})$. Signals for the trans-[Pt $(4-$ $\left.\mathrm{CNpy})_{2} \mathrm{Cl}_{2}\right]$ complex are labeled trans. Procedures for obtaining spectra starting from such nitrate salts are explained in the text.

However, relatively soon after addition of $\left[\mathrm{Et}_{4} \mathrm{~N}\right] \mathrm{Cl}$ to $\left[\mathrm{Pt}^{\mathrm{II}}(4-\right.$ $\left.\mathrm{Xpy})_{4}\right]\left(\mathrm{NO}_{3}\right)_{2}\left(\mathrm{X}=\mathrm{CN}(\mathbf{1 e}), \mathrm{CF}_{3}(\mathbf{2 e})\right.$, and $\left.\operatorname{MeCO}(\mathbf{6 e})\right)$ suspensions in the studies just mentioned above, new signals corresponding to the free 4-Xpy ligand and to the trans-[ $\mathrm{Pt}^{\mathrm{II}}(4-$ $\left.\mathrm{Xpy})_{2} \mathrm{Cl}_{2}\right]$ complex were detectable (see Figure 8 for $\mathrm{X}=\mathrm{CN}$ (1e); also see Supporting Information, Figure S6). Scheme 2 describes the most likely course of the reactions.

Effect of $\left[\mathrm{Et}_{4} \mathrm{~N}\right] \mathrm{Cl}$ on the $\mathrm{H} 2 / 6$ Signals of $\left[\mathrm{Pt}^{\mathrm{Il}}(4-\right.$ $\left.\mathrm{Xpy})_{4}\right]\left(\mathrm{PF}_{6}\right)_{2}$ and of [ $\mathrm{Pt}^{\prime \prime}\left(4-\mathrm{Mepy}_{4}\right] \mathrm{Y}_{2}$ Complexes in $\mathrm{CDCl}_{3}$ ( $\mathrm{X}=\mathrm{MeO}$ and $\left(\mathrm{CH}_{2}\right)_{5} \mathrm{~N}$, and $\mathrm{Y}=\mathrm{PF}_{6}{ }^{-}, \mathrm{BF}_{4}{ }^{-}$, and $\mathrm{NO}_{3}{ }^{-}$). In our studies of $5 \mathrm{mM}$ solutions of $\left[\mathrm{Pt}^{\mathrm{II}}(4-\mathrm{Xpy})_{4}\right] \mathrm{Y}_{2}$ complexes in various solvents, we ranked the ability of the $\mathrm{Y}$ anions both to form ion pairs and to form hydrogen bonds as follows: $\mathrm{Cl}^{-}>$ $\mathrm{NO}_{3}{ }^{-}>\mathrm{BF}_{4}^{-} \approx \mathrm{PF}_{6}^{-}$. We begin by describing results leading to this order with our assessment of the effects of addition of $\left[\mathrm{Et}_{4} \mathrm{~N}\right] \mathrm{Cl}$ to $\mathrm{CDCl}_{3}$ solutions of $\left[\mathrm{Pt}^{\mathrm{II}}(4-\mathrm{Xpy})_{4}\right]\left(\mathrm{PF}_{6}\right)_{2}[\mathrm{X}=$ $\mathrm{MeO}(3 \mathbf{b}),\left(\mathrm{CH}_{2}\right)_{5} \mathrm{~N}(\mathbf{5 b})$, and $\left.\mathrm{Me}(7 \mathbf{b})\right]$ complexes. Such an addition was expected to convert a $\left\{\left[\mathrm{Pt}^{\mathrm{II}}(4-\mathrm{Xpy})_{4}\right]^{2+}, 2 \mathrm{PF}_{6}{ }^{-}\right\}$ ion pair to a $\left\{\left[\mathrm{Pt}^{\mathrm{II}}(4-\mathrm{Xpy})_{4}\right]^{2+}, 2 \mathrm{Cl}^{-}\right\}$ion pair. The change of 
Scheme 2. Species Probably Formed (in $\mathrm{CD}_{3} \mathrm{CN}$ and $\mathrm{CDCl}_{3}$, $25^{\circ} \mathrm{C}$ ) after Addition of $\left[\mathrm{Et}_{4} \mathrm{~N}\right] \mathrm{Cl}$ to $\left[\mathrm{Pt}(4-\mathrm{Xpy})_{4}\right]\left(\mathrm{NO}_{3}\right)_{2}$ Complexes in Which 4-Xpy is a Weak Donor Ligand

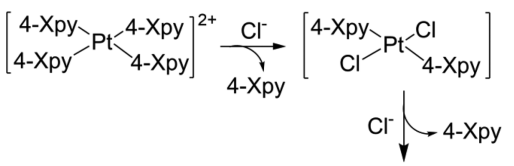

$$
\begin{aligned}
& {\left[\begin{array}{ccc}
4-\mathrm{Xpy}_{-} & \\
\mathrm{Cl}^{-} & -\mathrm{Pt}^{-} & \mathrm{Cl}
\end{array}\right]^{-}} \\
& \left.\left.\underset{\mathrm{Cl}^{-}}{\mathrm{Cl}} \stackrel{\mathrm{Pt}}{-\mathrm{Cl}}\right]_{\mathrm{Cl}}^{-\mathrm{Cl}^{-}}\right]^{2-}
\end{aligned}
$$

the counterion in the ion pair caused downfield shift changes of the $\mathrm{H} 2 / 6$ signals in $\mathrm{CDCl}_{3}$ (Figure 9 and Supporting Information, Figure S7).

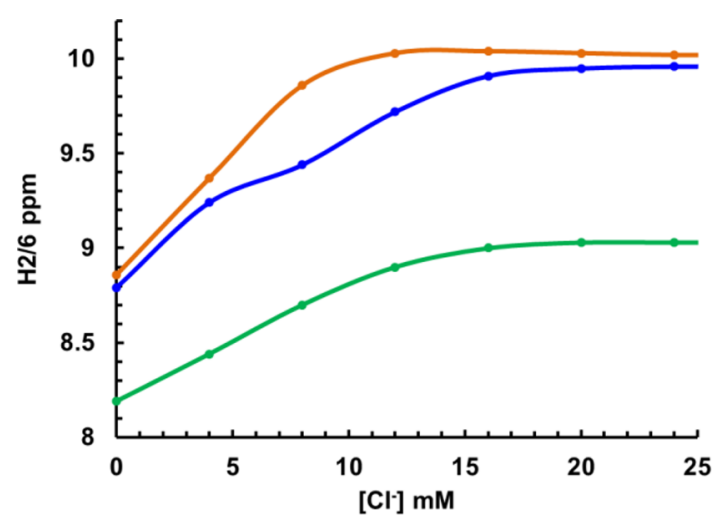

Figure 9. Shift of the $\mathrm{H} 2 / 6$ signal of $\left[\mathrm{Pt}(4-\mathrm{Mepy})_{4}\right]\left(\mathrm{PF}_{6}\right)_{2}(7 \mathbf{b}, 5 \mathrm{mM}$, orange), $\left[\mathrm{Pt}(4-\mathrm{MeOpy})_{4}\right]\left(\mathrm{PF}_{6}\right)_{2}(3 \mathbf{b}, 5 \mathrm{mM}$, blue $)$, and $[\mathrm{Pt}(4-$ $\left.\left.\left(\mathrm{CH}_{2}\right)_{5} \mathrm{Npy}\right)_{4}\right]\left(\mathrm{PF}_{6}\right)_{2}(\mathbf{5 b}, 5 \mathrm{mM}$, green $)$ upon addition of $\left[\mathrm{Et}_{4} \mathrm{~N}\right] \mathrm{Cl}$ $(0-25 \mathrm{mM})$ in $\mathrm{CDCl}_{3}$ at $25{ }^{\circ} \mathrm{C}$.

The curves showing the dependence of the downfield shift changes of $\mathrm{H} 2 / 6$ signals for $7 \mathbf{b}$ and $\mathbf{5 b}$ on adding $\left[\mathrm{Et}_{4} \mathrm{~N}\right] \mathrm{Cl}$ have the smooth shape most often found in our studies (Figure 9 and Supporting Information, Figure S7). For $\mathbf{5 b}$ (bearing the highly basic $4-\left(\mathrm{CH}_{2}\right)_{5} \mathrm{Npy}$ ligand), the $\left[\mathrm{Et}_{4} \mathrm{~N}\right] \mathrm{Cl}$ concentration (Figure 9 and Supporting Information, Figure S7) required to reach a plateau $(\sim 20 \mathrm{mM})$ was higher than that for $7 \mathbf{b}(\sim 12$ $\mathrm{mM})$, as expected, because $4-\left(\mathrm{CH}_{2}\right)_{5} \mathrm{Npy}$ in $\mathbf{5 b}$ is much more electron-rich than is 4-Mepy in $7 \mathbf{b}$. Thus, the $\delta+$ charge on the $\mathrm{H} 2 / 6$ protons is relatively smaller, and the $\mathrm{CH} \cdots \mathrm{Cl}$ interactions within the ion pair are weaker for $4-\left(\mathrm{CH}_{2}\right)_{5} \mathrm{Npy}$ in $\mathbf{5 b}$ than those for 4-Mepy in $7 \mathbf{b}$; a higher $\left[\mathrm{Cl}^{-}\right]$is therefore required by $\mathbf{5 b}$ than by $7 \mathbf{b}$ to fully form $\left\{\left[\mathrm{Pt}^{\mathrm{II}}(4-\mathrm{Xpy})_{4}\right]^{2+}, 2 \mathrm{Cl}^{-}\right\}$ion pairs. The $\mathrm{H} 2 / 6$ signals for $7 \mathbf{b}$ and $\mathbf{5 b}$ initially at 8.86 and $8.22 \mathrm{ppm}$ shifted downfield to $10.04 \mathrm{ppm}$ at $\sim 12 \mathrm{mM}\left[\mathrm{Cl}^{-}\right]$and 9.02 ppm at $\sim 20 \mathrm{mM}\left[\mathrm{Cl}^{-}\right]$, respectively (Figure 9 and Supporting Information, Figure S7). The shift change observed for $\mathbf{7 b}$ $(\sim 1.2 \mathrm{ppm})$ was much larger than for $\left[\mathrm{Pt}^{\mathrm{II}}\left(4-\left(\mathrm{CH}_{2}\right)_{5} \mathrm{Npy}\right)_{4}\right]$ $\left(\mathrm{PF}_{6}\right)_{2} \quad$ (5b) $(\sim 0.8 \mathrm{ppm})$. The smaller $\mathrm{H} 2 / 6$ shift change observed for $\mathbf{5 b}$, bearing the highly basic $4-\left(\mathrm{CH}_{2}\right)_{5} \mathrm{Npy}$ ligand, can be attributed to the electron richness of the pyridyl ring, which in turn lowers the partial positive charge of the $\mathrm{H} 2 / 6$ protons and diminishes the hydrogen-bonding ability of these hydrogens. The results for solutions are consistent with the solid-state data; the average nonbonding (py) $\mathrm{C}-\mathrm{H} \cdots \mathrm{Cl}$ distances observed for $\left[\mathrm{Pt}^{\mathrm{II}}\left(4-\left(\mathrm{CH}_{2}\right)_{5} \mathrm{Npy}\right)_{4}\right] \mathrm{Cl}_{2} \quad$ (5a) are slightly longer than those observed for $\left[\mathrm{Pt}^{\mathrm{II}}(4-\mathrm{Mepy})_{4}\right] \mathrm{Cl}_{2}$ (7a) (Supporting Information). These comparative results for $\mathbf{7 b}$ and $\mathbf{5 b}$ are readily rationalized only if specific contacts occur between the $\mathrm{Cl}^{-}$anion and the $\mathrm{H} 2 / 6$ protons in the ion pairs.

The curve of the shift changes observed for the $\mathrm{H} 2 / 6$ signal of $\left[\mathrm{Pt}^{\mathrm{II}}\left(4-\mathrm{MeOpy}_{4}\right] \mathrm{PF}_{6}(3 \mathbf{b})\right.$ has a different shape than those found for $\mathbf{5 b}$ and $\mathbf{7 b}$. This different shape was found in a few cases (Figure 9 and Supporting Information). Both $\mathbf{3 b}$ and $\mathbf{7 b}$ have moderately basic 4-Xpy ligands, and the starting and ending $\mathrm{H} 2 / 6$ shifts are very similar. Likewise, the $\mathrm{H} 2 / 6$ shift change upon addition of the first aliquot of $\sim 5 \mathrm{mM} \mathrm{Cl}^{-}(\sim 1$ equiv of $\left.\mathrm{Cl}^{-}\right)$is similar for $3 \mathbf{b}$ and $7 \mathbf{b}$. However, as more $\mathrm{Cl}^{-}$ was added, the chemical shift of the $\mathrm{H} 2 / 6$ signal of $3 \mathbf{b}$ plateaued and then increased again, and finally plateaued at a shift similar to that of $\mathbf{7 b}$. Such a finding cannot be easily explained if there are no specific contacts in the ion pair. However, if the first equivalent of added $\mathrm{Cl}^{-}$altered the canting angles within the $\left\{\left[\mathrm{Pt}^{\mathrm{II}}(4-\mathrm{MeOpy})_{4}\right]^{2+}, \mathrm{Cl}^{-}, \mathrm{PF}_{6}^{-}\right\}$ion pair, a higher amount of $\mathrm{Cl}^{-}$would then be needed for a second $\mathrm{Cl}^{-}$ to fully displace the remaining $\mathrm{PF}_{6}{ }^{-}$from this ion pair to form the $\left\{\left[\mathrm{Pt}^{\mathrm{II}}(4-\mathrm{MeOpy})_{4}\right]^{2+}, 2 \mathrm{Cl}^{-}\right\}$ion pair.

To assess the effect of counterions other than $\mathrm{PF}_{6}^{-}$on $\mathrm{Cl}^{-}$ ion-pairing interactions with $\left[\mathrm{Pt}^{\mathrm{II}}(4-\mathrm{Xpy})_{4}\right]^{2+},\left[\mathrm{Et}_{4} \mathrm{~N}\right] \mathrm{Cl}$ addition experiments using $\left[\mathrm{Pt}^{\mathrm{II}}(4-\mathrm{Mepy})_{4}\right]\left(\mathrm{BF}_{4}\right)_{2}(7 \mathrm{c})$ and $\left[\mathrm{Pt}^{\mathrm{II}}(4-\mathrm{Mepy})_{4}\right]\left(\mathrm{NO}_{3}\right)_{2}$ (7e) were conducted (Figure 10 and

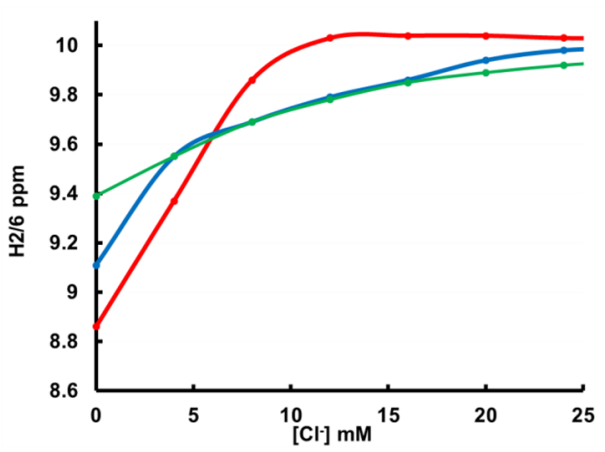

Figure 10. Shift of the $\mathrm{H} 2 / 6$ signal of $\left[\mathrm{Pt}(4-\mathrm{Mepy})_{4}\right]\left(\mathrm{PF}_{6}\right)_{2}(7 \mathbf{b}, 5$ $\mathrm{mM}$, red), $\left[\mathrm{Pt}(4-\mathrm{Mepy})_{4}\right]\left(\mathrm{BF}_{4}\right)_{2}(7 \mathrm{c}, 5 \mathrm{mM}$, blue), and $[\mathrm{Pt}(4-$ Mepy $\left.)_{4}\right]\left(\mathrm{NO}_{3}\right)_{2}(7 \mathrm{e}, 5 \mathrm{mM}$, green $)$ upon addition of $\left[\mathrm{Et}_{4} \mathrm{~N}\right] \mathrm{Cl}$ up to $25 \mathrm{mM}$ in $\mathrm{CDCl}_{3}$ at $25{ }^{\circ} \mathrm{C}$.

Supporting Information, Figure S9). As the $\left[\mathrm{Et}_{4} \mathrm{~N}\right] \mathrm{Cl}$ concentration was increased from $0-125 \mathrm{mM}$, the $\mathrm{H} 2 / 6$ signals for $7 \mathrm{c}$ and $7 \mathrm{e}$ shifted downfield from 9.11 and $9.39 \mathrm{ppm}$ to 10.02 and $10.00 \mathrm{ppm}$, respectively. The shift change of the $\mathrm{H} 2 / 6$ signal $(\sim 1.2 \mathrm{ppm})$ observed for $\left[\mathrm{Pt}^{\mathrm{II}}(4-\mathrm{Mepy})_{4}\right]\left(\mathrm{PF}_{6}\right)_{2}$ (7b) was more than that observed for $7 \mathbf{c}(\sim 0.9 \mathrm{ppm})$ and $7 \mathbf{e}$ $\left(\sim 0.6 \mathrm{ppm}\right.$, in $\mathrm{CDCl}_{3}$ at $\left.25{ }^{\circ} \mathrm{C}\right)$. The concentration of $\left[\mathrm{Et}_{4} \mathrm{~N}\right]$ $\mathrm{Cl}$ required to reach a plateau was much lower $(\sim 13 \mathrm{mM})$ for $7 \mathbf{b}$ (with the $\mathrm{PF}_{6}^{-}$anion) than for $7 \mathbf{c}(\sim 25 \mathrm{mM})$ or $7 \mathbf{e}(\sim 50$ $\mathrm{mM}$ ) (with the $\mathrm{BF}_{4}^{-}$or $\mathrm{NO}_{3}^{-}$counterions, respectively). Of greater interest, the curve for $7 \mathrm{c}$ rose sharply to an $\sim 1: 1$ ratio of $\mathrm{Cl}^{-}$, and then rose more gradually. This curve indicates that very likely a mixed $\left\{\left[\mathrm{Pt}^{\mathrm{II}}(4-\mathrm{Mepy})_{4}\right]^{2+}, \mathrm{Cl}^{-}, \mathrm{BF}_{4}^{-}\right\}$ion pair forms readily with one $\mathrm{Cl}^{-}$and one $\mathrm{BF}_{4}{ }^{-}$, as proposed above for the $\left\{\left[\mathrm{Pt}^{\mathrm{II}}(4-\mathrm{MeOpy})_{4}\right]^{2+}, \mathrm{Cl}^{-}, \mathrm{PF}_{6}{ }^{-}\right\}$ion pair. Perhaps the $\mathrm{H}$ bonding interactions within the $\left\{\left[\mathrm{Pt}^{\mathrm{II}}(4-\mathrm{Xpy})_{4}\right]^{2+}, \mathrm{Cl}^{-}, \mathrm{BF}_{4}^{-}\right\}$ ion pair causes changes in the canting of the bound 4-Mepy ligands. The solid-state structural data show that large changes in canting are feasible. Such a change in canting could favor $\mathrm{H}$ - 
bonding by the tetrahedral $\mathrm{BF}_{4}{ }^{-}$remaining in the mixed ion pair. The $\mathrm{BF}_{4}^{-}$could then be more difficult to substitute from the mixed ion pair than the octahedral $\mathrm{PF}_{6}{ }^{-}$in the $\left\{\left[\mathrm{Pt}^{\mathrm{II}}(4-\right.\right.$ $\left.\left.\mathrm{Xpy})_{4}\right]^{2+}, \mathrm{Cl}^{-}, \mathrm{PF}_{6}^{-}\right\}$ion pair. In any case, the shape of the curve is further evidence that there are specific contacts within these ion pairs. The interaction of the $\mathrm{Y}$ anions with the $\mathrm{H} 2 / 6$ protons in $\left\{\left[\mathrm{Pt}^{\mathrm{II}}(4-\mathrm{Xpy})_{4}\right]^{2+}, 2 \mathrm{Y}^{-}\right\}$ion pairs thus decreases in the order: $\mathrm{Cl}^{-}>\mathrm{NO}_{3}^{-}>\mathrm{BF}_{4}^{-} \approx \mathrm{PF}_{6}^{-}$.

Shift of the $\mathrm{H} 2 / 6$ Signals of $\left[\mathrm{Pt}^{\mathrm{Il}}(4-\mathrm{Xpy})_{4}\right]\left(\mathrm{NO}_{3}\right)_{2}$ and Other $\left[\mathrm{Pt}^{\prime \prime}(4-\mathrm{Xpy})_{4}\right] \mathrm{Y}_{2}$ Complexes in $\mathrm{CD}_{3} \mathrm{CN}$. When the counterion is not chloride, $\left[\mathrm{Pt}^{\mathrm{II}}(4-\mathrm{Xpy})_{4}\right] \mathrm{Y}_{2}$ salts are often not soluble in $\mathrm{CDCl}_{3}$ (cf. Table 2). We decided to conduct broader studies in the more polar solvents in the hope that we could obtain data relevant to ion pairing on more $\left[\mathrm{Pt}^{\mathrm{II}}(4-\mathrm{Xpy})_{4}\right] \mathrm{Y}_{2}$ compounds in a given solvent. Because $\mathrm{D}_{2} \mathrm{O}$ and DMSO- $d_{6}$ are too polar to allow extensive ion pairing (Supporting Information), we chose to explore $\mathrm{CD}_{3} \mathrm{CN}$. All $\left[\mathrm{Pt}^{\mathrm{II}}(4-\right.$ $\left.\mathrm{Xpy})_{4}\right] \mathrm{Y}_{2}$ complexes prepared in this study were soluble at 5 $\mathrm{mM}$ concentration in $\mathrm{CD}_{3} \mathrm{CN}$. This solvent was polar enough to allow NMR spectra to be recorded at $25{ }^{\circ} \mathrm{C}$ but was not so polar as to preclude formation of ion pairs (Tables 3 and S8). Furthermore, addition of $\left[\mathrm{Et}_{4} \mathrm{~N}\right] \mathrm{Cl}$ to the chloride salt, $\left[\mathrm{Pt}^{\mathrm{II}}(4-\right.$ $\left.\left.\mathrm{Me}_{2} \mathrm{Npy}\right)_{4}\right] \mathrm{Cl}_{2}(4 \mathrm{a})$, in $\mathrm{CD}_{3} \mathrm{CN}$ caused a downfield shift of 0.33 ppm of the $\mathrm{H} 2 / 6$ signal (Table 3 ). This finding indicates that the ion pair is not fully formed in $\mathrm{CD}_{3} \mathrm{CN}$. In contrast, $\left[\mathrm{Et}_{4} \mathrm{~N}\right.$ ] $\mathrm{Cl}$ addition to $\mathbf{4 a}$ and other chloride salts in $\mathrm{CDCl}_{3}$ led to upfield $\mathrm{H} 2 / 6$ shifts (Figure S5), indicating that the ion pair was fully formed in the less polar $\mathrm{CDCl}_{3}$ solvent.

${ }^{1} \mathrm{H}$ NMR spectra of $\left[\mathrm{Pt}^{\mathrm{II}}(4-\mathrm{Xpy})_{4}\right]\left(\mathrm{NO}_{3}\right)_{2} \mathrm{CD}_{3} \mathrm{CN}$ solutions were recorded $\sim 5 \mathrm{~min}$ after addition of sufficient $\left[\mathrm{Et}_{4} \mathrm{~N}\right] \mathrm{Cl}$ to make the solutions $50.0 \mathrm{mM}$ in $\left[\mathrm{Et}_{4} \mathrm{~N}\right] \mathrm{Cl}$. For all five complexes studied, downfield $\mathrm{H} 2 / 6$ shift changes were observed as expected (Table 3, Figure 11, and Supporting

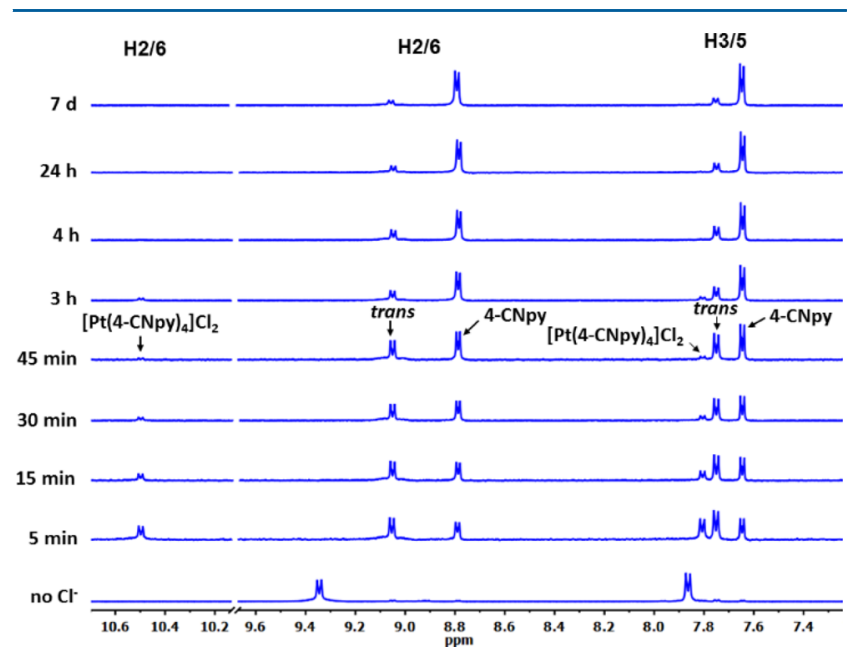

Figure 11. Stacked plot of the aromatic region of ${ }^{1} \mathrm{H}$ NMR spectra (in $\left.\mathrm{CD}_{3} \mathrm{CN}, 25{ }^{\circ} \mathrm{C}\right)$ for the treatment of $\left[\mathrm{Pt}(4-\mathrm{CNpy})_{4}\right]\left(\mathrm{NO}_{3}\right)_{2}(\mathbf{1 e}, 5$ $\mathrm{mM})$ with $\left[\mathrm{Et}_{4} \mathrm{~N}\right] \mathrm{Cl}(50 \mathrm{mM})$. Signals for trans- $\left[\mathrm{Pt}(4-\mathrm{CNpy})_{2} \mathrm{Cl}_{2}\right]$ are labeled trans.

Information, Figures S10-S12). The $\mathrm{H} 2 / 6$ shift changes observed for $\left[\mathrm{Pt}^{\mathrm{II}}(4-\mathrm{CNpy})_{4}\right]\left(\mathrm{NO}_{3}\right)_{2}(\sim 1.2 \mathrm{ppm}), \quad\left[\mathrm{Pt}^{\mathrm{II}}(4-\right.$ $\mathrm{CF}_{3}$ py $\left.)_{4}\right]\left(\mathrm{NO}_{3}\right)_{2} \quad(\sim 1.1 \mathrm{ppm}), \quad\left[\mathrm{Pt}^{\mathrm{II}}(4-\mathrm{MeCOpy})_{4}\right]\left(\mathrm{NO}_{3}\right)_{2}$ $(\sim 1.2 \mathrm{ppm})$, and $\left[\mathrm{Pt}^{\mathrm{II}}(4-\mathrm{MeOpy})_{4}\right]\left(\mathrm{NO}_{3}\right)_{2}(\sim 1.2 \mathrm{ppm})$ were greater than the $0.75 \mathrm{ppm}$ observed for $\left[\mathrm{Pt}^{\mathrm{II}}\left(4-\mathrm{Me}_{2} \mathrm{Npy}\right)_{4}\right]$ $\left(\mathrm{NO}_{3}\right)_{2}$ (Table 3). Such larger $\mathrm{H} 2 / 6$ shift changes indicate that $\mathrm{H}$ bonding to $\mathrm{Cl}$ is better when 4-Xpy is a poor or moderate donor with low pyridyl-ring electron richness and hence greater partial positive charge, $\delta^{+}$, on the $\mathrm{H} 2 / 6$ protons. Thus, ion pairs with specific interactions in $\mathrm{CD}_{3} \mathrm{CN}$ are similar in nature to those in $\mathrm{CDCl}_{3}$, although $\mathrm{CD}_{3} \mathrm{CN}$ is more polar.

${ }^{1} \mathrm{H}$ NMR signals of "free" 4-Xpy and trans- $\left[\mathrm{Pt}^{\mathrm{II}}(4-\mathrm{Xpy})_{2} \mathrm{Cl}_{2}\right]$ in the first spectrum recorded $(\sim 5 \mathrm{~min})$ after $\left[\mathrm{Et}_{4} \mathrm{~N}\right] \mathrm{Cl}$ addition to $\left[\mathrm{Pt}^{\mathrm{II}}(4-\mathrm{CNpy})_{4}\right]\left(\mathrm{NO}_{3}\right)_{2}$ (1e), $\left[\mathrm{Pt}^{\mathrm{II}}\left(4-\mathrm{CF}_{3} \mathrm{py}\right)_{4}\right]$ $\left(\mathrm{NO}_{3}\right)_{2}(\mathbf{2 e})$, and $\left[\mathrm{Pt}^{\mathrm{II}}(4-\mathrm{MeCOpy})_{4}\right]\left(\mathrm{NO}_{3}\right)_{2}(\mathbf{6 e})$ in $\mathrm{CD}_{3} \mathrm{CN}$ at $25{ }^{\circ} \mathrm{C}$ (Figure 11 and Supporting Information, Figures S10$\mathrm{S} 12)$. Less time was required for the intensity of the aromatic signals of $\left[\mathrm{Pt}^{\mathrm{II}}(4-\mathrm{CNpy})_{4}\right] \mathrm{Cl}_{2}(\sim 4 \mathrm{~h})$ and $\left[\mathrm{Pt}^{\mathrm{II}}\left(4-\mathrm{MeCOpy}_{4}\right]\right.$ $\mathrm{Cl}_{2}(\sim 6 \mathrm{~h})$ to reach the baseline than in the case of $\left[\mathrm{Pt}^{\mathrm{II}}(4-\right.$ $\mathrm{CF}_{3}$ py $\left.)_{4}\right] \mathrm{Cl}_{2}(\sim 24 \mathrm{~h})$. Therefore, the donor ability of 4-Xpy decreases in the order $\mathrm{X}=\mathrm{CF}_{3}>\mathrm{CN} \approx \mathrm{MeCO}$. For a detailed discussion of the spectral changes over time, see Supporting Information.

\section{CONCLUSIONS}

The dependence of the chemical shifts of 4-Xpy $\mathrm{H} 2 / 6{ }^{1} \mathrm{H}$ NMR signals of many new complexes in two series, namely, trans- $\left[\mathrm{Pt}^{\mathrm{II}}(4-\mathrm{Xpy})_{2} \mathrm{Cl}_{2}\right]$ and $\left[\mathrm{Pt}^{\mathrm{II}}(4-\mathrm{Xpy})_{4}\right] \mathrm{Y}_{2}$, were investigated by employing 4-Xpy with very diverse donor abilities. For both series in $\mathrm{CDCl}_{3}$, downfield shift changes $(\Delta \delta)$ were observed for the $\mathrm{H} 2 / 6$ signals upon coordination of 4-Xpy to form the respective trans- $\left[\mathrm{Pt}^{\mathrm{II}}(4-\mathrm{Xpy})_{2} \mathrm{Cl}_{2}\right]$ or $\left[\mathrm{Pt}(4-\mathrm{Xpy})_{4}\right] \mathrm{Cl}_{2}$ complexes. The size of $\mathrm{H} 2 / 6 \Delta \delta$ decreased linearly with increasing 4 -Xpy donor ability. The decrease in $\Delta \delta$ was greater for the $\left[\mathrm{Pt}(4-\mathrm{Xpy})_{4}\right] \mathrm{Cl}_{2}$ series than for the trans-[ $\left.\mathrm{Pt}^{\mathrm{II}}(4-\mathrm{Xpy})_{2} \mathrm{Cl}_{2}\right]$ series. We conclude that this finding can be attributed to the synergistic reduction in the inductive effect of the $\mathrm{Pt}(\mathrm{II})$ center by the other three 4 -Xpy donor ligands in the $\left[\mathrm{Pt}(4-\mathrm{Xpy})_{4}\right] \mathrm{Cl}_{2}$ series as compared to only one other 4 -Xpy donor ligand in the trans- $\left[\mathrm{Pt}^{\mathrm{II}}(4-\mathrm{Xpy})_{2} \mathrm{Cl}_{2}\right]$ series.

Solutions of $\left[\mathrm{Pt}(4-\mathrm{Xpy})_{4}\right] \mathrm{Cl}_{2}$ salts in $\mathrm{CDCl}_{3}$ have very downfield 4-Xpy $\mathrm{H} 2 / 6{ }^{1} \mathrm{H}$ NMR signals and exhibit much larger $\mathrm{H} 2 / 6 \Delta \delta$ values than those of the corresponding $\left[\mathrm{Pt}^{\mathrm{II}}(4-\right.$ $\left.\mathrm{Xpy})_{4}\right] \mathrm{Y}_{2}\left(\mathrm{Y}=\mathrm{PF}_{6}, \mathrm{BF}_{4}\right.$, and $\left.\mathrm{NO}_{3}\right)$ salts. We conclude that strong ion pairing between $\mathrm{Cl}^{-}$and $\left[\mathrm{Pt}^{\mathrm{II}}(4-\mathrm{Xpy})_{4}\right]^{2+}$ is facilitated by multiple $\mathrm{H} 2 / 6 \cdots \mathrm{Cl}^{-} \mathrm{H}$-bonding contacts, explaining the large downfield shifts. Also, strong ion pairing explains the high solubility of the $\left[\mathrm{Pt}^{\mathrm{II}}(4-\mathrm{Xpy})_{4}\right] \mathrm{Cl}_{2}$ salts that contain a $\left[\mathrm{Pt}^{\mathrm{II}}(4-\mathrm{Xpy})_{4}\right]^{2+}$ dication. Other $\left[\mathrm{Pt}^{\mathrm{II}}(4-\mathrm{Xpy})_{4}\right] \mathrm{Y}_{2}$ salts were often much less soluble or even insoluble. Crystal structures revealed that the chloride counterions occupy axial positions with nonbonding (py) $\mathrm{C}-\mathrm{H} \cdots \mathrm{Cl}$ distances well within the range of a typical $\mathrm{CH} \cdots \mathrm{Cl} \mathrm{H}$-bonding contact $(2.4-3.0 \AA)$. Thus, the crystallographic data confirm our conclusion that the relatively larger $\mathrm{H} 2 / 6 \Delta \delta$ values (in $\mathrm{CDCl}_{3}$ at $25{ }^{\circ} \mathrm{C}$ ) observed for $\left[\mathrm{Pt}^{\mathrm{II}}(4-\mathrm{Xpy})_{4}\right] \mathrm{Cl}_{2}$ arise from ion pairing, which in turn is stabilized by multiple (py)C-H...Cl contacts.

Several ${ }^{1} \mathrm{H}$ NMR studies in various solvents allowed us to correlate the dependence of the relative stability of the ion pairs of $\left[\mathrm{Pt}^{\mathrm{II}}(4-\mathrm{Xpy})_{4}\right] \mathrm{Y}_{2}$ based on their H-bonding ability as follows: $\mathrm{Cl}^{-}>\mathrm{NO}_{3}^{-}>\mathrm{BF}_{4}^{-}>\mathrm{PF}_{6}^{-}$. The poor solubility of some $\left[\mathrm{Pt}^{\mathrm{II}}(4-\mathrm{Xpy})_{4}\right] \mathrm{Y}_{2}\left(\mathrm{Y}=\mathrm{PF}_{6}, \mathrm{BF}_{4}\right.$, and $\left.\mathrm{NO}_{3}\right)$ complexes as compared to the $\left[\mathrm{Pt}^{\mathrm{II}}(4-\mathrm{Xpy})_{4}\right] \mathrm{Cl}_{2}$ analogues is probably a result of the weaker ion pairing.

Because our procedures for synthesizing model trans- $\left[\mathrm{Pt}^{\mathrm{II}}(4-\right.$ $\left.\mathrm{Xpy})_{2} \mathrm{Cl}_{2}\right]$ and $\left[\mathrm{Pt}^{\mathrm{II}}(4-\mathrm{Xpy})_{4}\right] \mathrm{Y}_{2}$ complexes do not rely on high temperatures, water solubility, or Xpy volatility, the methods are clearly applicable to other nonvolatile monodentate ligands, such as those bearing biological targeting groups. The NMR spectroscopic trends we have elucidated can serve as a guide 
during the synthesis and characterization of such $\mathrm{Pt}(\mathrm{II})$ complexes.

\section{ASSOCIATED CONTENT}

\section{S Supporting Information}

The Supporting Information is available free of charge on the ACS Publications website at DOI: 10.1021/acs.inorgchem.7b01294.

Details of the syntheses and characterization of all complexes prepared in this study; descriptions and figures of the effect of $\left[\mathrm{Et}_{4} \mathrm{~N}\right] \mathrm{Cl}$ addition on ${ }^{1} \mathrm{H} \mathrm{NMR}$ signals of $\left[\mathrm{Pt}^{\mathrm{II}}(4-\mathrm{Xpy})_{4}\right] \mathrm{Y}_{2}$ in various solvents; descriptions and figures of replacement of weak 4-Xpy ligands by chloride upon $\left[\mathrm{Et}_{4} \mathrm{~N}\right] \mathrm{Cl}$ addition to $\left[\mathrm{Pt}^{\mathrm{II}}(4-\mathrm{Xpy})_{4}\right]$ $\left(\mathrm{NO}_{3}\right)_{2}$ suspensions or solutions; tables of crystallographic data for complexes 2, 3, 4', 5, 3a, 4a, 5a, and 7a in CIF format; tables of selected nonbonding $\mathrm{Pt} \cdot \cdots \mathrm{Cl}$ and (py) $\mathrm{C}-\mathrm{H} \cdots \mathrm{Cl}$ distances and dihedral angles; tables of ${ }^{1} \mathrm{H}$ NMR data in $\mathrm{CDCl}_{3}$ for py and various $\mathrm{Pt}(\mathrm{II})$ py complexes and for trans-[Pt(4-Xpy) $\left.)_{2} \mathrm{Cl}_{2}\right]$ complexes; tables of ${ }^{1} \mathrm{H}$ NMR shift data in $\mathrm{CDCl}_{3}, \mathrm{CD}_{3} \mathrm{CN}$, DMSO- $d_{6}$, and $\mathrm{D}_{2} \mathrm{O}$ for free 4-Xpy and for $[\mathrm{Pt}(4-$ $\left.\mathrm{Xpy})_{4}\right] \mathrm{Y}_{2}$ complexes both with and without added $\left[\mathrm{Et}_{4} \mathrm{~N}\right] \mathrm{Cl}$; figure showing the orientation of the pyridyl rings relative to the coordination plane in cis- $[\mathrm{Pt}(4-$ $\left.\mathrm{Me}_{2} \mathrm{Npy}\right)_{2} \mathrm{Cl}_{2}$ ]; plots of ${ }^{1} \mathrm{H}$ NMR data versus $\mathrm{p} K_{\mathrm{a}}$ for free ligand and for trans- $\left[\mathrm{Pt}(4-\mathrm{Xpy})_{2} \mathrm{Cl}_{2}\right]$ (including $\mathrm{X}=\mathrm{H}$ ) in $\mathrm{CDCl}_{3}$ (PDF)

\section{Accession Codes}

CCDC 1551057-1551064 contain the supplementary crystallographic data for this paper. These data can be obtained free of charge via www.ccdc.cam.ac.uk/data_request/cif, or by emailing data_request@ccdc.cam.ac.uk, or by contacting The Cambridge Crystallographic Data Centre, 12 Union Road, Cambridge CB2 1EZ, UK; fax: +44 1223336033.

\section{AUTHOR INFORMATION}

\section{Corresponding Author}

*E-mail: lmarzil@lsu.edu.

\section{ORCID}

Patricia A. Marzilli: 0000-0002-8103-9606

Luigi G. Marzilli: 0000-0002-0406-0858

Notes

The authors declare no competing financial interest.

\section{ACKNOWLEDGMENTS}

Upgrade of the diffractometer was made possible through Grant No. LEQSF(2011-12)-ENH-TR-01, administered by the Louisiana Board of Regents.

\section{REFERENCES}

(1) Lewis, N. A.; Marzilli, P. A.; Fronczek, F. R.; Marzilli, L. G. Models for $\mathrm{B}_{12}$-Conjugated Radiopharmaceuticals. Cobaloxime Binding to New fac- $\left[\operatorname{Re}(\mathrm{CO})_{3}\left(\mathrm{Me}_{2}\right.\right.$ Bipyridine)(Amidine) $] \mathrm{BF}_{4}$ Complexes Having an Exposed Pyridyl Nitrogen. Inorg. Chem. 2014, 53 (20), 11096-11107.

(2) Kelland, L. The Resurgence of Platinum-Based Cancer Chemotherapy. Nat. Rev. Cancer 2007, 7 (8), 573-584.

(3) Wilson, J. J.; Lippard, S. J. In Vitro Anticancer Activity of cisDiammineplatinum(II) Complexes with $\beta$-Diketonate Leaving Group Ligands. J. Med. Chem. 2012, 55 (11), 5326-5336.
(4) Jakupec, M. A.; Galanski, M.; Arion, V. B.; Hartinger, C. G.; Keppler, B. K. Antitumor Metal Compounds: More Than Theme and Variations. Dalton Trans. 2008, 2, 183-194.

(5) Wheate, N. J.; Walker, S.; Craig, G. E.; Oun, R. The Status of Platinum Anticancer Drugs in the Clinic and in Clinical Trials. Dalton Trans. 2010, 39 (35), 8113-8127.

(6) Klein, A. V.; Hambley, T. W. Platinum Drug Distribution in Cancer Cells and Tumors. Chem. Rev. 2009, 109 (10), 4911-4920.

(7) Warad, I.; Eftaiha, A. a. F.; Al-Nuri, M. A.; Husein, A. I.; Assal, M.; Abu-Obaid, A.; Al-Zaqri, N.; Ben Hadda, T.; Hammouti, B. Metal Ions as Antitumor Complexes - Review. J. Mater. Environ. Sci. 2013, 4 (4), 542-557.

(8) Kalinowska-Lis, U.; Ochocki, J.; Matlawska-Wasowska, K. Trans Geometry in Platinum Antitumor Complexes. Coord. Chem. Rev. 2008, 252 (12-14), 1328-1345.

(9) Li, C.; Huang, R.-R.; Ding, Y.; Sletten, E.; Arnesano, F.; Losacco, M.; Natile, G.; Liu, Y.-Z. Effect of Thioethers on DNA Platination by Trans-Platinum Complexes. Inorg. Chem. 2011, 50 (17), 8168-8176.

(10) Aleman, J.; del Solar, V.; Cubo, L.; Quiroga, A. G.; Navarro Ranninger, C. New Reactions of Anticancer-Platinum Complexes and their Intriguing Behaviour Under Various Experimental Conditions. Dalton Trans. 2010, 39 (44), 10601-10607.

(11) Coluccia, M.; Natile, G. Trans-Platinum Complexes in Cancer Therapy. Anti-Cancer Agents Med. Chem. 2007, 7 (1), 111-123.

(12) Li, C.; Ding, Y.; Cheng, L.; Zheng, Y.; Sletten, E.; Liu, Y. Effects of Buffers and $\mathrm{pH}$ on the Reaction of a Trans-Platinum Complex with 5'-Guanosine Monophosphate. Eur. J. Inorg. Chem. 2015, 2015, 49144920.

(13) Coluccia, M.; Nassi, A.; Loseto, F.; Boccarelli, A.; Mariggio, M. A.; Giordano, D.; Intini, F. P.; Caputo, P.; Natile, G. A Trans-Platinum Complex Showing Higher Antitumor Activity than the Cis Congeners. J. Med. Chem. 1993, 36, 510-512.

(14) Montero, E. I.; Diaz, S.; Gonzalez-Vadillo, A. M.; Perez, J. M.; Alonso, C.; Navarro-Ranninger, C. Preparation and Characterization of Novel trans-[ $\mathrm{PtCl}_{2}$ (Amine)(Isopropylamine)] Compounds: Cytotoxic Activity and Apoptosis Induction in Ras-Transformed Cells. J. Med. Chem. 1999, 42 (20), 4264-4268.

(15) Aris, S. M.; Farrell, N. P. Towards Antitumor Active TransPlatinum Compounds. Eur. J. Inorg. Chem. 2009, 2009, 1293-1302.

(16) Filipovic, L.; Arandelovic, S.; Gligorijevic, N.; Krivokuca, A.; Jankovic, R.; Srdic-Rajic, T.; Rakic, G.; Tesic, Z.; Radulovic, S. Biological Evaluation of Trans-Dichloridoplatinum(II) Complexes with 3- and 4-Acetylpyridine in Comparison to Cisplatin. Radiol. Oncol. 2013, 47 (4), 346-357.

(17) Rakic, G. M.; Grguric-Sipka, S.; Kaluderovic, G. N.; GomezRuiz, S.; Bjelogrlic, S. K.; Radulovic, S. S.; Tesic, Z. L. Novel TransDichloroplatinum(II) Complexes with 3- and 4-Acetylpyridine: Synthesis, Characterization, DFT Calculations and Cytotoxicity. Eur. J. Med. Chem. 2009, 44 (5), 1921-1925.

(18) Leng, M.; Locker, D.; Giraud-Panis, M.-J.; Schwartz, A.; Intini, F. P.; Natile, G.; Pisano, C.; Boccarelli, A.; Giordano, D.; Coluccia, M. Replacement of an $\mathrm{NH}_{3}$ by an Iminoether in Transplatin makes an Antitumor Drug from an Inactive Compound. Mol. Pharmacol. 2000, 58 (6), 1525-1535.

(19) Saad, J. S.; Benedetti, M.; Natile, G.; Marzilli, L. G. Basic Coordination Chemistry Relevant to DNA Adducts Formed by the Cisplatin Anticancer Drug. NMR Studies on Compounds with Sterically Crowded Chiral Ligands. Inorg. Chem. 2010, 49 (12), $5573-5583$.

(20) Saad, J. S.; Benedetti, M.; Natile, G.; Marzilli, L. G. NMR Studies of Models Having the $\mathrm{Pt}(\mathrm{d}(\mathrm{GpG}))$ 17-Membered Macrocyclic Ring Formed in DNA by Platinum Anticancer Drugs: Pt Complexes with Bulky Chiral Diamine Ligands. Inorg. Chem. 2011, 50 (10), $4559-4571$

(21) Andrepont, C.; Marzilli, P. A.; Marzilli, L. G. Guanine Nucleobase Adducts Formed by $[\mathrm{Pt}(\mathrm{di}-(2$-picolyl $)$ amine $) \mathrm{Cl}] \mathrm{Cl}$ : Evidence That a Tridentate Ligand with Only in-Plane Bulk Can Slow Guanine Base Rotation. Inorg. Chem. 2012, 51 (21), 1196111970. 
(22) Andrepont, C.; Marzilli, P. A.; Pakhomova, S.; Marzilli, L. G. Guanine Nucleobase Adducts Formed by a Monofunctional Complex: [Pt(N-(6-methyl-2-picolyl)-N-(2-picolyl)amine)Cl]Cl. J. Inorg. Biochem. 2015, 153, 219-230.

(23) Pazderski, L.; Szlyk, E.; Sitkowski, J.; Kamienski, B.; Kozerski, L.; Tousek, J.; Marek, R. Experimental and Quantum-Chemical Studies of ${ }^{15} \mathrm{~N}$ NMR Coordination Shifts in Palladium and Platinum Chloride Complexes with Pyridine, 2,2'-Bipyridine and 1,10-Phenanthroline. Magn. Reson. Chem. 2006, 44 (2), 163-170.

(24) Tessier, C.; Rochon, F. D. Multinuclear NMR Study and Crystal Structures of Complexes of the Types Cis- and Trans-Pt $(\mathrm{Ypy})_{2} \mathrm{X}_{2}$, where $\mathrm{Ypy}=$ Pyridine Derivative and $\mathrm{X}=\mathrm{Cl}$ and I. Inorg. Chim. Acta 1999, 295 (1), 25-38.

(25) Thompson, L. K. Trans Platinum(II) Complexes with Pyridine and Substituted Pyridines. Inorg. Chim. Acta 1980, 38, 117-119.

(26) Kauffman, G. B.; Thompson, R. J.cis- and trans-Dichloro(dipyridine)Platinum(II). In Inorganic Syntheses; John Wiley \& Sons, Inc.: Hoboken, NJ, 1963; Vol. 7, pp 249-253.

(27) Pazderski, L.; Tousek, J.; Sitkowski, J.; Malinakova, K.; Kozerski, L.; Szlyk, E. Experimental and Quantum-Chemical Studies of ${ }^{1} \mathrm{H},{ }^{13} \mathrm{C}$ and ${ }^{15} \mathrm{~N}$ NMR Coordination Shifts in $\mathrm{Au}(\mathrm{III}), \mathrm{Pd}(\mathrm{II})$ and $\mathrm{Pt}(\mathrm{II})$ Chloride Complexes with Picolines. Magn. Reson. Chem. 2009, 47 (3), 228-238.

(28) Perera, T.; Abhayawardhana, P.; Marzilli, P. A.; Fronczek, F. R.; Marzilli, L. G. Formation of a Metal-to-Nitrogen Bond of Normal Length by a Neutral Sufonamide Group within a Tridentate Ligand. A New Approach to Radiopharmaceutical Bioconjugation. Inorg. Chem. 2013, 52 (5), 2412-2421.

(29) Saad, J. S.; Marzilli, P. A.; Intini, F. P.; Natile, G.; Marzilli, L. G. Single-Stranded Oligonucleotide Adducts Formed by Pt Complexes Favoring Left-Handed Base Canting: Steric Effect of Flanking Residues and Relevance to DNA Adducts Formed by Pt Anticancer Drugs. Inorg. Chem. 2011, 50 (17), 8608-8620.

(30) Andrepont, C.; Pakhomova, S.; Marzilli, P. A.; Marzilli, L. G. Unusual Example of Chelate Ring Opening Upon Coordination of the 9-Ethylguanine Nucleobase to [Pt(di-(6-methyl-2-picolyl)amine $) \mathrm{Cl}$ Cl. Inorg. Chem. 2015, 54 (10), 4895-4908.

(31) Thompson, L. K. Trans Platinum(II) Complexes with Pyridine and Substituted Pyridines. Inorg. Chim. Acta 1980, 38 (1), 117-119.

(32) Watt, G. W.; Thompson, L. K.; Pappas, A. J. Tetrakis and Bis Platinum(II) Iodide Complexes with Pyridine and SubstitutedPyridine Ligands. Inorg. Chem. 1972, 11 (4), 747-749.

(33) Sokolenko, V. A.; Bondarenko, V. S.; Korniets, E. D.; Kovtonyuk, N. P.; Kovrova, N. B. Solid-Phase Condensation of Coordinated Pyridine and $\gamma$-Picoline in Patinum(II) Complexes. Zh. Neorg. Khim. 1989, 34 (6), 1537-1540.

(34) Bondarenko, V. S.; Korniets, E. D.; Sokolenko, V. A.; Kovrova, N. B.; Kovtonyuk, N. P. Thermolysis of Platinum(IV) Complexes of Pyridine and $\gamma$-Picoline. Zh. Neorg. Khim. 1989, 34 (6), 1541-1543.

(35) Pazderski, L.; Pawlak, T.; Sitkowski, J.; Kozerski, L.; Szlyk, E. Structural Correlations for ${ }^{1} \mathrm{H},{ }^{13} \mathrm{C}$ and ${ }^{15} \mathrm{~N}$ NMR Coordination Shifts in $\mathrm{Au}(\mathrm{III}), \mathrm{Pd}(\mathrm{II})$ and $\mathrm{Pt}(\mathrm{II})$ Chloride Complexes with Lutidines and Collidine. Magn. Reson. Chem. 2010, 48 (6), 417-426.

(36) Hambley, T. W. van der Waals Radii of Pt(II) and Pd(II) in Molecular Mechanics Models and an Analysis of Their Relevance to

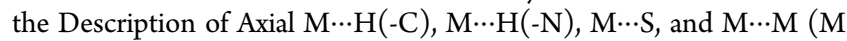
$=\mathrm{Pd}(\mathrm{II})$ or $\mathrm{Pt}(\mathrm{II}))$ Interactions. Inorg. Chem. 1998, 37 (15), 37673774.

(37) Bondi, A. Van der Waals Volumes and Radii. J. Phys. Chem. 1964, 68 (3), 441-451.

(38) Price, J. H.; Williamson, A. N.; Schramm, R. F.; Wayland, B. B. Palladium(II) and Platinum(II) Alkyl Sulfoxide Complexes. Examples of Sulfur-Bonded, Mixed Sulfur- and Oxygen-Bonded, and Totally Oxygen-Bonded Complexes. Inorg. Chem. 1972, 11 (6), 1280-1284.

(39) Sheldrick, G. M. SADABS; University of Göttingen: Germany, 1997.

(40) Sheldrick, G. M. A Short History of SHELX. Acta Crystallogr., Sect. A: Found. Crystallogr. 2008, A64, 112-122.
(41) Colamarino, P.; Orioli, P. L. Crystal and Molecular Structures of Cis- and Trans-Dichlorobis(pyridine)Platinum(II). J. Chem. Soc., Dalton Trans. 1975, 16-17, 1656-1659.

(42) Maheshwari, V.; Bhattacharyya, D.; Fronczek, F. R.; Marzilli, P. A.; Marzilli, L. G. Chemistry of HIV-1 Virucidal Pt Complexes Having Neglected Bidentate sp2 N-Donor Carrier Ligands with Linked Triazine and Pyridine Rings. Synthesis, NMR Spectral Features, Structure, and Reaction with Guanosine. Inorg. Chem. 2006, 45 (18), $7182-7190$

(43) Pitteri, B.; Marangoni, G.; Cattalini, L.; Visentin, F.; Bertolasi, V.; Gilli, P. The Role of the Non-Participating Groups in Substitution Reactions at Cationic $\mathrm{Pt}(\mathrm{II})$ Complexes Containing Tridentate Chelating Nitrogen Donors. Crystal Structure of $\{\mathrm{Pt}[\mathrm{bis}(2-$ pyridylmethyl)amine $](\mathrm{py})\}\left(\mathrm{CF}_{3} \mathrm{SO}_{3}\right)_{2}$. Polyhedron 2001, 20 (9-10), 869-880.

(44) Wei, C. H.; Hingerty, B. E.; Busing, W. R. Structure of Tetrakis(pyridine)Platinum(II) Chloride Trihydrate: Unconstrained Anisotropic Least-Squares Rrefinement of Hydrogen and Non Hydrogen Atoms from Combined X-Ray-Neutron Diffraction Data. Acta Crystallogr., Sect. C: Cryst. Struct. Commun. 1989, C45 (1), 26-30.

(45) de Medeiros, V. C.; de Andrade, R. B.; Leitao, E. F. V.; Ventura, E.; Bauerfeldt, G. F.; Barbatti, M.; do Monte, S. A. Photochemistry of $\mathrm{CH}_{3} \mathrm{Cl}$ : Dissociation and $\mathrm{CH} \cdots \mathrm{Cl}$ Hydrogen Bond Formation. J. Am. Chem. Soc. 2016, 138 (1), 272-280.

(46) Thallapally, P. K.; Nangia, A. A Cambridge Structural Database Analysis of the C-H...Cl Interaction: $\mathrm{C}-\mathrm{H} \cdots \mathrm{Cl}-$ and $\mathrm{C}-\mathrm{H} \cdots \mathrm{Cl}-\mathrm{M}$ often Behave as Hydrogen Bonds but $\mathrm{C}-\mathrm{H} \cdots \mathrm{Cl}-\mathrm{C}$ is Generally a Van der Waals Interaction. CrystEngComm 2001, 3, 1-6.

(47) Thallapally, P. K.; Nangia, A. A Cambridge Structural Database Analysis of the C-H..Cl Interaction: $\mathrm{C}-\mathrm{H} \cdots \mathrm{Cl}^{-}$and $\mathrm{C}-\mathrm{H} \cdots \mathrm{Cl}-\mathrm{M}$ Often Behave as Hydrogen Bonds but $\mathrm{C}-\mathrm{H} \cdots \mathrm{Cl}-\mathrm{C}$ is Generally a Van der Waals Interaction. CrystEngComm 2001, 3 (27), 114-119.

(48) Aakeroy, C. B.; Evans, T. A.; Seddon, K. R.; Palinko, I. The CH...Cl Hydrogen Bond: Does it Exist? New J. Chem. 1999, 23 (2), $145-152$.

(49) Bresciani-Pahor, N.; Forcolin, M.; Marzilli, L. G.; Randaccio, L.; Summers, M. F.; Toscano, P. J. Organocobalt $B_{12}$ Models: Axial Ligand Effects on the Structural and Coordination Chemistry of Cobaloximes. Coord. Chem. Rev. 1985, 63, 1-125.

(50) Hibbert, F.; Emsley, J. Hydrogen Bonding and Chemical Reactivity. Adv. Phys. Org. Chem. 1990, 26, 255-279.

(51) Konrat, R.; Tollinger, M.; Kontaxis, G.; Krautler, B. NMR Techniques to Study Hydrogen Bonding in Aqueous Solution. Monatsh. Chem. 1999, 130 (8), 961-982.

(52) Stilinovic, V.; Kaitner, B. Salts and Co-Crystals of Gentisic Acid with Pyridine Derivatives: The Effect of Proton Transfer on the Crystal Packing (and Vice Versa). Cryst. Growth Des. 2012, 12 (11), $5763-5772$

(53) Bortoluzzi, M.; Annibale, G.; Marangoni, G.; Paolucci, G.; Pitteri, B. ${ }^{31} \mathrm{P}$ NMR and DFT Studies on Square-Planar Bis(Diphenylphosphinoethyl)Phenylphosphine (Triphos) Complexes of Pt(II) with Pyridines and Anilines. Polyhedron 2006, 25 (9), 19791984.

(54) Scriven, E. F. V.; Murugan, R. Kirk-Othmer Encyclopedia of Chemical Technology; John Wiley \& Sons, Inc.: Hoboken, NJ, 2006; Vol. 21, pp 91-133.

(55) Dawson, R. M. C. Data for Biochemical Research, 3rd ed.; Oxford Science Publications: Oxford, England, 1986; p 580.

(56) Honda, H. ${ }^{1} \mathrm{H}-\mathrm{MAS}-\mathrm{NMR}$ Chemical Shifts in HydrogenBonded Complexes of Chlorophenols (Pentachlorophenol, 2,4,6Trichlorophenol, 2,6-Dichlorophenol, 3,5-Dichlorophenol, and $p$ Chlorophenol) and Amine, and H/D Isotope Effects on ${ }^{1} \mathrm{H}-\mathrm{MAS}$ NMR Spectra. Molecules 2013, 18, 4786-4802. 